\title{
Understanding the effect of shifting cultivation practice (slash-burn-cultivation-abandonment) on soil physicochemical properties in the North-eastern Himalayan region
}

\author{
Entendiendo el efecto de la agricultura itinerante \\ (tala-quema-cultivo-abandono) en las propiedades físico-químicas \\ del suelo en la región del Noroeste del Himalaya
}

\author{
Gaurav Mishra ${ }^{1^{*}}$ \\ Krishna Giri \\ Abhishek Jangir ${ }^{3}$ \\ Duraisamy Vasu ${ }^{4}$ \\ Jesús Rodrigo-Comino ${ }^{5,6^{*}}$ (i)
}

\begin{abstract}
Shifting cultivation (jhum cultivation), a common practice of converting forest land into agricultural land by slash and burn is threatening the ecosystem. This study assesses the effect of shifting cultivation cycles on soil quality in the North-eastern Himalayan region using a minimum of soil properties. To achieve this goal, a soil quality index (SQI) approach and multivariate techniques were used for surface $(0-30 \mathrm{~cm})$ and subsurface $(30-70 \mathrm{~cm})$ layers of soils in the forest, jhum land, and jhum fallow areas. The highest variability among land uses was found for clay content, SOC (soil organic carbon), exchangeable $\mathrm{Mg}$ and $\mathrm{K}, \mathrm{CEC}$ (cation exchange capacity), and the Ca/Mg relationship. On the contrary, the lowest variation was recorded in bulk density (BD), porosity, and $\mathrm{pH}$. The results of the principal component analysis (PCA) show BD, soil texture, available nitrogen (Nav), available phosphorus (Pav), available potassium (Kav), calcium ( $\mathrm{Ca}$ ) and sodium ( $\mathrm{Na}$ ) as the major indicators of soil quality. The study indicated that surface layers of forest soils have a lower soil quality when compared to jhum lands. Although jhum lands show a better soil quality compared to forests, their continued cultivation without any fertilisation and subsequent depletion of the soil nutrients can cause a degradation of soil quality as observed in jhum fallow lands. The use of these selected indicators for soil quality assessment was useful in terms of saving time and costs.
\end{abstract}

Keywords: Land management; traditional agricultural systems; jhum; forest; soil quality index.

\footnotetext{
1 Rain Forest Research Institute, Jorhat, Assam, India - 785001. gaurav.mishra215@gmail.com. *Corresponding author

2 Rain Forest Research Institute, Jorhat, Assam, India - 785001. krishna.goswami87@gmail.com

3 National Bureau of Soil Survey \& Land Use Planning, Nagpur, India - 440033. abhishekjangir1988@gmail.com

4 National Bureau of Soil Survey \& Land Use Planning, Nagpur, India - 440033. d.plantdoctor@gmail.com

5 Departamento de Análisis Geográfico Regional y Geografía Física, Facultad de Filosofía y Letras, Campus Universitario de Cartuja, University of Granada, 18071 Granada, Spain. jesusrc@ugr.es

6 Department of Physical Geography, University of Trier, 54296 Trier, Germany. * Corresponding author
} 


\section{Resumen}

La agricultura itinerante (jhum), una práctica común para convertir tierras forestales en tierras agrícolas mediante la tala y quema, podría amenazar la provisión de servicios ecosistémicos. El presente estudio tuvo como objetivo evaluar el efecto de los ciclos de cultivo itinerante sobre la calidad del suelo en la región del noreste del Himalaya utilizando el mínimo número posible de propiedades del suelo. Para lograr este objetivo, se utilizó un enfoque de índice de calidad del suelo (SQI) y técnicas multivariadas para horizontes superficiales $(0-30 \mathrm{~cm})$ y subsuperficiales $(30-70 \mathrm{~cm})$ de suelos en las áreas de bosque, tierrascultivadas y barbecho. La mayor variabilidad entre los usos de la tierra se encontró para el contenido de arcilla, CO (carbono orgánico del suelo), Mg y K intercambiables, CEC (capacidad de intercambio catiónico) y relación $\mathrm{Ca} / \mathrm{Mg}$. Por el contrario, la menor variación se registró en densidad aparente (BD), porosidad y $\mathrm{pH}$. Los resultados del análisis de componentes principales (ACP) mostraron $\mathrm{BD}$, textura del suelo, nitrógeno disponible (Nav), fósforo disponible (Pav), potasio disponible (Kav), calcio ( $\mathrm{Ca}$ ) y sodio ( $\mathrm{Na}$ ) como los principales indicadores capaces de explicar la calidad del suelo. Los resultados indicaron que las capas superficiales de los suelos forestales tienen una menor calidad de suelo en comparación con las tierras cultivadas. Aunque las tierras cultivadas muestran una mejor calidad del suelo en comparación con los bosques, su cultivo continuo sin fertilización y el consiguiente agotamiento de los nutrientes del suelo pueden causar una degradación de la calidad del suelo como se observa en las tierras en barbecho. El uso de estos indicadores seleccionados en la evaluación de la calidad del suelo fue útil en términos de reducción en el costo y el tiempo de análisis.

Palabras clave: Gestion de tierras; sistemas agrícolas tradicionales; Jhum; Bosque; Índice de calidad del suelo.

\section{Introduction}

Soils are key resources for human activities and natural ecosystems (Rodrigo-Comino, López-Vicente, et al., 2020), therefore establish suitable indicators to assess their quality has been key for scholars around the world such as in the Mediterranean belt (e.g. Ceccarelli, Bajocco, Perini, \& Salvati, 2014; Colantoni, Ferrara, Perini, \& Salvati, 2015; Sánchez-Navarro et al., 2015). However, due to the wide ranges of human activities and under an eminent climate change that modifies the main soil physicochemical properties, a clear regional methodological approaches still non-well known (Assefa, Elias, Soromessa, \& Ayele, 2020; Coyle et al., 2017; Gbejewoh, Keesstra, \& Blancquaert, 2021). For example, the process of converting the forest land by slash and burn into annual crops called "shifting cultivation" (Singh, Bordoloi, Kumar, Hazarika \& Parmar et al., 2014). This is a common practice carried out in Africa, Asia and Latin America and able to contribute to 70,50 and $16 \%$ of the total deforestation, respectively (FAO, 1957; Inoue et al. 2010; Chaplot, Bouahom \& Valentin, 2010).

The Northeastern Himalayan (NEH) region of India is characterized by unique agro-ecological conditions, which makes it the centre of speciation for many plant species (Mishra \& Sarkar, 2020). It is one of the twelve biodiversity hot-spots in the world, having $65 \%$ of its area under forests and $16 \%$ under agriculture (Saha, Chaudhary \& Somasundaram, 2012). The major agriculture practice and source of income in the NEH is the shifting cultivation locally known as jhum (Yadav, 2013). This shifting cultivation cycle is characterized by certain stages, starting from the selection of site, slashing and burning of native vegetation, crop cultivation from 1 to 2 years and leaving the land abandoned from 10 to 12 years. The same cycle is continuously repeated for so many decades but sometimes unfavourable changes in soil quality have been noticed. In the last few decades, specifically, shifting cultivation is leading to rapid changes in land uses in the Nagaland state of NEH (Patel, Karmakar, Sanjog, Kumar \& Chowdhury et al., 2013; Chase \& Singh, 2014).

The intensive crop cultivation with no external input from 2 to 4 years after slashing and burning the native forest is causing a significant decline in soil quality (Ayoubi, Khormali, Sahrawat \&Rodrigues De Lima, 2011; Sarkar et al., 2015). For example, Handayani (2004) reported that the cultivated fields after the clearance in the tropical forest of Sumatra resulted in a high loss of organic matter, a reduction in labile carbon (C) pools and a drastically declining in biological activity. The continuous cultivation in deforested sites is also able to reduce soil cation exchange capacity (CEC), as it was demonstrated in Ethiopia (Mulugeta, Karltun, \& Olsson, 2005; Nega \&Heluf, 2009). Sulieman, Saeed, Hassaballa, \& Rodrigo-Comino (2018) also reported the lower values of CEC and other soil properties in urban soils, due to intensive human inferences in Sudan. A reduction in these parameters can lead to various deleterious effects such as soil erosion, biodiversity loss, acidification, soil compaction, desertification and climate 
change (Chase \& Singh, 2014; Rodrigo-Comino, Terol, Mora, Giménez-Morera, \& Cerdà, 2020; Salehi, Wilhelmsson, \& Soderberg, 2008; Salvati, Bajocco, Ceccarelli, Zitti, \& Perini, 2011).

The studies on the effects of forest conversion to temporary agricultural lands (jhum) on the dynamics of organic $C$ stock and soil health have recently received the attention of policymakers and forest managers (IPCC, 2007). Earlier reports from the NEH region indicates that the cycle of conversion from the forest into jhum lands and from jhum land into fallow jhum territories show negatively influences on the physicochemical properties of soil, with a loss of soil organic carbon (SOC) (Ramakrishnan and Toky, 1981; Aruchalam, 2002). For example, Sarkar et al. (2015) reported an increase in the concentration of plant-available phosphorus $(\mathrm{P})$, potassium $(\mathrm{K})$, calcium $(\mathrm{Ca})$ and magnesium $(\mathrm{Mg})$ after burning but a drastic decrease in SOC content. Ribeiro Filho, Adams, \& Murrieta (2013) reviewed the literature published on this topic and discussed the soil variables used to evaluate the effect of the jhum cultivation. According to them, texture, structure, density, colour, retention of humidity, and temperature were considered as the main physical soil properties, meanwhile, $\mathrm{pH}$, dynamics of macronutrients, CEC, SOM, total carbon (Total $\mathrm{C}$ ) and total nitrogen (Total $\mathrm{N}$ ) were the most important chemical ones. Thus, we can observe that inconsistent conclusions have been drawn from different studies because of the limits of the understanding of the effects of the jhum cycle on soil quality in both the short and long-term. Moreover, studies evaluating the influence of different land use on soil quality under tropical and sub-humid forest conditions are also limited (Enaruvbe \& Atafo, 2019; Lohbeck, Poorter, Martínez-Ramos \& Bongers,2015; Poorter et al., 2015). Hence, it is important to evaluate the influence of the jhum cycle on soil quality, and specifically, in the NEH region of India, where it occupies 1.47 million hectares and mainly is practised by tribal communities.

Many kinds of soil quality indexes (SQI) have been developed to assess the soil quality under different land uses and climatic conditions across the world (e.g. Marzaioli, D'Ascoli, De Pascale, \& Rutigliano2010; Li, Zhang, Wang, \& Yu., 2013; Rodrigo-Comino, Keshavarzi, Bagherzadeh \& Brevik2019). For example, Mishra et al, (2017) worked out the soil quality of jhum lands in comparison to tropical semi-evergreen forests of Nagaland in India, using PCA-LSF-SQIw (principal component analysis-linear scoring functionsweighted soil quality index) approach. These results demonstrated that these indexes can be applied to jhum areas. All of this information should be included as a useful tool to design suitable and effective land management plans by reducing the number of variables and conclusions obtained for each type of land use. However, there is a lack of information about that currently. We state that it is necessary to fill this gap considering the sustainable development goals and clear objectives to achieve land degradation neutrality by policymakers and stakeholders (Visser, Keesstra, Maas, de Cleen\& Molenaar, 2019).

Given these facts, the current study aims to focus on studying the variability in soil properties under forest, jhum land, and jhum fallow land, using the minimum number of soil properties to assess the possible soil quality changes prior to designing a land management plan. To achieve this goal, a combination of multivariate statistical analysis and soil weighted quality indexes are applied in the NEH. We hypothesize that principal component analysis (PCA) and minimum dataset (MDS), in combination with additive and weighted index methods, are the best approaches to obtain useful information for policymakers and land managers at the first stage of a holistic and regional geographic evaluation.

\section{Methods}

\subsection{Study area}

The study was carried out in the Kohima district of Nagaland. Situated in the NEH region of India $\left(25^{\circ} 40^{\prime}-25^{\circ} 67^{\prime} \mathrm{N}, 94^{\circ} 07-94^{\circ} 12^{\prime} \mathrm{E}\right)$, the district occupies an area of about $1,463 \mathrm{~km}^{2}$. The elevation ranges from 690 to $1261 \mathrm{~m}$ a.s.l. The average annual rainfall is $1,831 \mathrm{~mm}$, where $90 \%$ is distributed from May to October. The monthly mean temperature in the district ranges between $27-32{ }^{\circ} \mathrm{C}$ (Mishra, Jangir \& Francaviglia, 2019). The majority of the forest areas are situated in the Kohima region and are classified as tropical wet evergreen forest. The major tree species of the selected forest sites ( $>25$ years old) are Alnus nepalensis, Duabanga grandiflora, Gmelina arborea, Grevillea robusta, Melia azadirachta, Macaranga denticulate, and Pinus kesiya. In jhum lands, mainly it can be found the upland rice (Oryza sativa) which is cultivated under conventional practices such as dry seeding with no proper arrangement of sowing, water supply and weeding (Rathore, 2008). The other important species include maize (Zea mays), cowpea (Vigna unguiculata), Colocasia (Colocasia esculenta), chilli (Capsicum annuum), pumpkin (Cucurbita peto), and brinjal (Solanum melongena). Alnus nepalensis is the unique tree that can be found in fallow jhum lands along, which is combined with common weeds (Eleusine indica; Amaranthus viridis; Chromolaena 
odorata; Mimosa pudica; and Imperata cylindrica). On the other, the jhum fields selected in this study were one-year-old (cleared the previous year for cultivation). Finally, the fallow jhum lands were left as fallow for more than five years after cultivation. A brief description of sampling sites (Figure 1, prepared in Arc-GIS) is presented in Table 1. Soils can be classified as Acrisols (IUSS-WRB, 2015), and are derived from tertiary rocks, belongs to Barail and Disang series, respectively. The soils contain fine loamy to clay loam texture and with limited depth, usually characterized by low organic matter and base saturation. However, the accumulation of clay in the sub-surface horizon can be found.

\subsection{Soil sampling and analysis}

A total of 12 sites were randomly selected in the forest (5), jhum (4) and fallow jhum (3) lands and soil profiles were excavated, in mid-slope, up to bedrock to study the variability in soil properties (Figure 2). Fiftysoil samples (horizon wise) were collected: 21 in the forest, 16 in jhum and 13 in jhum fallows. Replicated soil samples (three) were immediately stored in polyethene bags and subsequently processed before laboratory analysis.

The samples were air-dried at room temperature $\left(22^{\circ} \mathrm{C}\right)$ to constant weight and sieved through a 2-mm sieve to exclude litter, roots and coarse particles. The hydrometer method was employed for particle size analysis (Klute, 1986) to calculate clay, silt and sand contents. Bulk density (BD) was estimated by the core method (Blake and Hartge, 1986). Total porosity was calculated from the bulk density results assuming a particle density of $2.65 \mathrm{~g} \mathrm{~cm}^{-3}$ (USDA, 2004) Soil $\mathrm{pH}$ was determined in 1:2 soil-water suspensions using a digital pH meter. Soil organic carbon (SOC) (Walkley and Black, 1934), available phosphorus (Pav) (Bray \& Kurtz, 1945), and available nitrogen (Subbiah \& Asija, 1956) (Nav) was determined following the earlier described standard methods. Available potassium (Kav), cation exchange capacity (CEC) and exchangeable cations $(\mathrm{Ca}, \mathrm{Na}, \mathrm{K}$, and $\mathrm{Mg}$ ) were estimated by $1 \mathrm{~N}$ ammonium acetate ( $\mathrm{pH} 7.0$ ) method (Schollenberger and Simon, 1945; Summer and Miller, 1996). Base saturation (BS) was estimated as the ratio of total bases to CEC.

Table 1. Land use, label, size and geographical information of the studied sites

\begin{tabular}{|c|c|c|c|c|c|c|}
\hline Land use & Label & Village & $\begin{array}{l}\text { Geographic coordinates } \\
\text { (Lat./Long.) }\end{array}$ & $\begin{array}{l}\text { Altitude } \\
\text { (m a.s.l.) }\end{array}$ & Major vegetation & $\begin{array}{l}\text { Soil depth } \\
(\mathrm{cm})\end{array}$ \\
\hline \multirow{5}{*}{ Forest } & FS1 & Khonoma & $\begin{array}{l}25.64305556 \\
94.01719444\end{array}$ & 1,531 & Alnus nepalensis, Melia azadirach & 70 \\
\hline & FS2 & Mariema & $\begin{array}{l}25.73411111 \\
94.05388889\end{array}$ & 1,296 & Grevillea robusta & 103 \\
\hline & FS3 & Jakhama & $\begin{array}{l}25.57552778 \\
94.12863889\end{array}$ & 1,626 & $\begin{array}{l}\text { Alnus nepalensis, Duabanga grandiflora, } \\
\text { Gmelina arborea, Melia azadirach, Macaranga } \\
\text { denticulate, Pinus kesiya }\end{array}$ & 118 \\
\hline & FS4 & Chedma & $\begin{array}{c}25.6935 ; \\
94.14297222\end{array}$ & 1,426 & Grevillea robusta & 98 \\
\hline & FS5 & Rusoma & $\begin{array}{l}25.71122222 \\
94.13558333\end{array}$ & 1,402 & Grevillea robusta & 92 \\
\hline \multirow{4}{*}{ Jhum } & Jhl & Mariema & $\begin{array}{l}25.74566667 \\
94.08555556\end{array}$ & 1,300 & Rice & 70 \\
\hline & Jh2 & Kewama & $\begin{array}{c}25.60925 \\
94.12419444\end{array}$ & 1,600 & Rice & 83 \\
\hline & Jh3 & Chedma & $\begin{array}{l}25.68833333 \\
94.15102778\end{array}$ & 1,375 & Beans, chili, Colocasia & 78 \\
\hline & Jh4 & Phesema & $\begin{array}{l}25.62672222 \\
94.11077778\end{array}$ & 1,625 & Maize, pumpkin, Colocasia & 73 \\
\hline \multirow{3}{*}{$\begin{array}{l}\text { Fallow } \\
\text { jhum }\end{array}$} & FJhl & Khonoma & $\begin{array}{l}25.63577778 \\
94.00780556\end{array}$ & 1,854 & $\begin{array}{l}\text { Eluesine indica,Amaranthus viridis, } \\
\text { Chromolaena odorata,Mimosa pudica, Imperata } \\
\text { cylindrica }\end{array}$ & 103 \\
\hline & FJh2 & Khonoma & $\begin{array}{c}25.79792 \\
94.70644444\end{array}$ & 1,400 & $\begin{array}{l}\text { Alnus nepalensis, Eluesine indica,Amaranthus } \\
\text { viridis, Chromolaena odorata, }\end{array}$ & 56 \\
\hline & FJh3 & Rusoma & $\begin{array}{l}25.72533333 \\
94.13922222\end{array}$ & 1,458 & $\begin{array}{l}\text { Alnus nepalensis, Chromolaena odorata, Mimosa } \\
\text { pudica }\end{array}$ & 80 \\
\hline
\end{tabular}

Own elaboration 
Figure 1. Sampling point sites in different land use
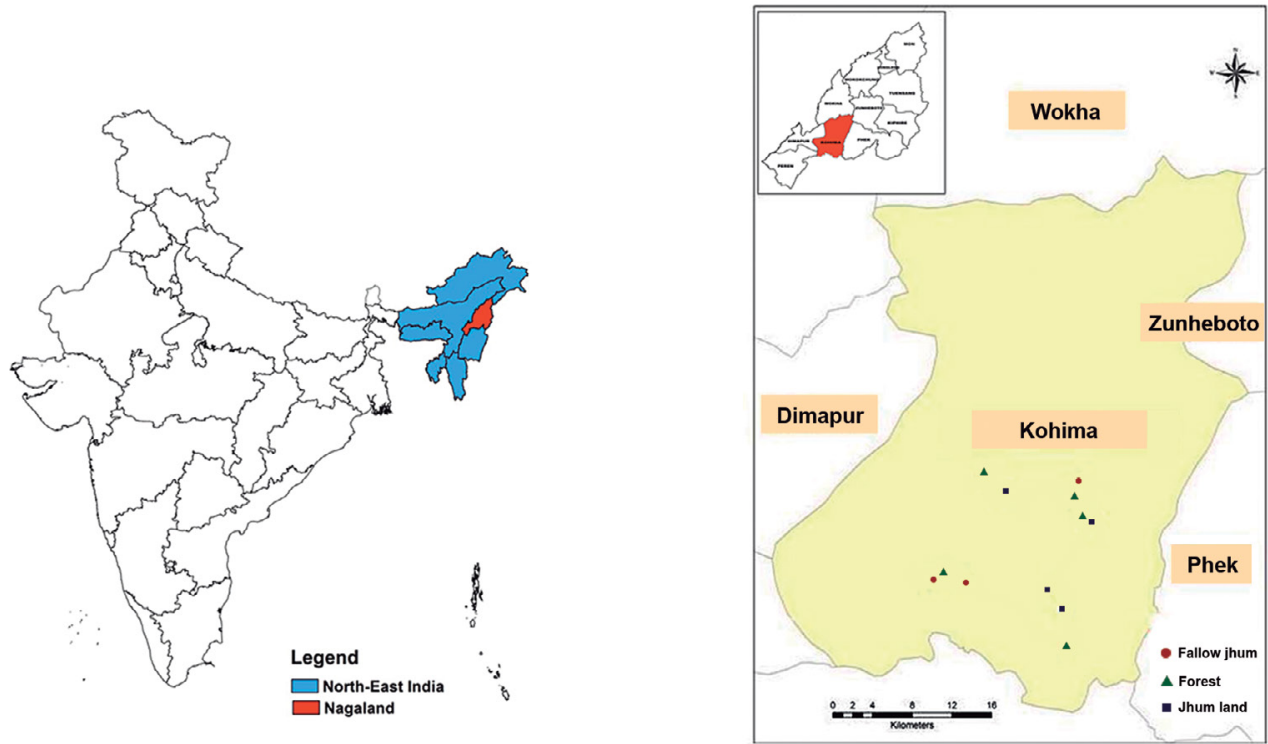

Own elaboration

\subsection{Data analysis}

\subsubsection{Descriptive statistics and variability analysis}

General statistics parameters such as minimum and maximum values, mean, standard deviation, the coefficient of variation and skewness were calculated for each land use, using the whole soil profile data. To check the normality of the data, a Shapiro-Wilks test was also carried out. After that, the variability of the measured soil properties among land-use types was tested using a one-way analysis of variance (ANOVA) followed by Duncan's multiple range test $(\mathrm{p}<0.05)$.

\subsubsection{Soil quality index evaluation}

As the depth of different horizons was not homogenized, so weighted mean of SQI values at two different depths $(0-30$ and $30-70 \mathrm{~cm})$ was fixed. This will also represent the dynamic soil quality $(0-30 \mathrm{~cm})$, which is more influenced by anthropogenic practices, while, the inherent soil quality of the different land uses is represented by $30-70 \mathrm{~cm}$ depth. In Figure 2, soil profiles from the study sites are illustrated.

Figure 2. Excavated soil profiles (a: forest; b: jhum and c: fallow jhum)

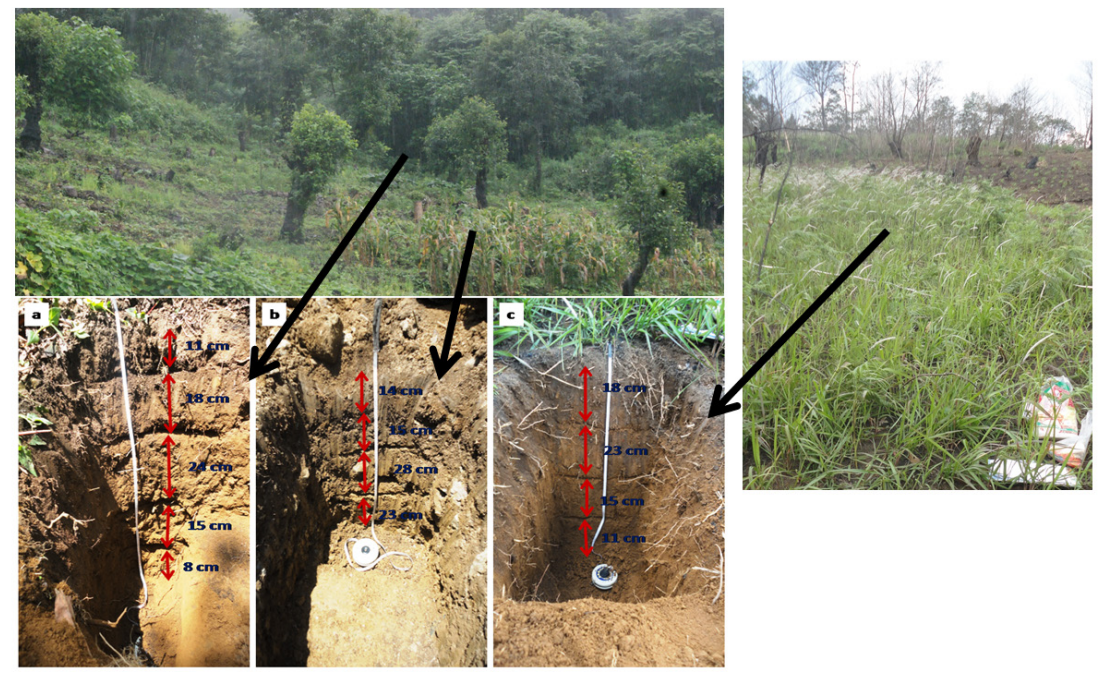

Own elaboration 
The dataset of the 17 soil physicochemical properties of each land use was subjected to PCA (Andrews, Karlen, \& Mitchell, 2002; Liu, Zhou, Shen, Li, Liang, Wang, \& Sun, 2014). The objective of PCA was to reduce the dimension of data while minimising the loss of information (Armenise, Redmile-Gordon, Stellacci, Ciccarese, \&Rubino, 2013). After running the PCA, the soil variable with high eigenvalues in each principal component (PC) under each land use is included in the minimum dataset (MDS) and considered best representatives explaining the variability (Andrews et al., 2002). Then, linear scoring functions (LSFs) were used to transform the selected variables, by arranging them in ascending order ('more is better' function) or descending order ('less is better' functions) (Andrews, Flora, Mitchell, \& Karlen2003). Later, the additive and weighted SQI was calculated using the methodology described by Vasu et al. (2016). All tests were performed using SPSS Version 16.0 (IBM Corporation, Armonk, NY).

\section{Results}

\subsection{Soil properties under different land use}

Physical and chemical soils properties from forest, jhum, and fallow jhum are presented in Suppl. Material 1, 2 and 3, respectively. Also, in suppl. material 4, 5and 6, the variation of soil properties along the soil profiles are depicted. Among the three different land-use types, a higher mean value of BD is recorded in the jhum lands $\left(1.06 \mathrm{Mg} \mathrm{m}^{-3}\right)$, followed by the forest $\left(1.02 \mathrm{Mg} \mathrm{m}^{-3}\right)$ and the fallow jhum $\left(0.90 \mathrm{Mg} \mathrm{m}^{-3}\right)$. The mean clay content is higher (28.3\%) in forest lands than jhum and fallow jhum (21.9 and $14.3 \%$, respectively). Soils under fallow jhum are relatively more porous $(66.2 \%)$ than the soils of the other two land uses. The forest soils register acidic to slightly acidic values ( $\mathrm{pH} 3.56-6.25)$ in reaction, whereas soils of jhum land and fallow jhum are slightly acidic to neutral (Table 3 and 4 ). The mean value of SOC is the highest in fallow jhum (1.6\%), followed by the forests (1.2\%) and jhum lands (1.0\%). However, under different land uses, the SOC content ranges from 0.4 to $3.1 \%$ (forest), 0.40 to $1.6 \%$ ( $\mathrm{hhum}$ ), and 0.4 to

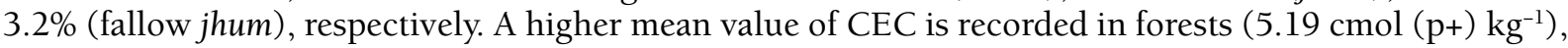
followed by jhum $\left(4.46 \mathrm{cmol}(\mathrm{p}+) \mathrm{kg}^{-1}\right)$ and jhum fallow $\left(3.97 \mathrm{cmol}(\mathrm{p}+) \mathrm{kg}^{-1}\right)$. In the case of exchangeable cations, the value of $\mathrm{Ca}\left(1.74 \mathrm{cmol}(\mathrm{p}+) \mathrm{kg}^{-1}\right) \mathrm{K}\left(1.00 \mathrm{cmol}(\mathrm{p}+) \mathrm{kg}^{-1}\right)$ and $\mathrm{Ca}: \mathrm{Mg}(1.87)$ are the highest for forest soils, whereas fallow jhum has the highest $\mathrm{Mg}(2.08 \mathrm{cmol}(\mathrm{p}+) \mathrm{kg}-1)$. Ex. Na content registers the maximum values $\left(0.85 \mathrm{cmol}(\mathrm{p}+) \mathrm{kg}^{-1}\right)$ in jhum lands. Among the primary macronutrients, $\mathrm{Nav}\left(418.68 \mathrm{~kg} \mathrm{ha}^{-1}\right)$ and $\mathrm{Kav}\left(256.65 \mathrm{~kg} \mathrm{ha}^{-1}\right)$ content reach the maximum values in forest soils, whereas jhum land soils have more Pav content $\left(27.96 \mathrm{~kg} \mathrm{ha}^{-1}\right)$.

Table 2. Effect of land use on soil properties

\begin{tabular}{|c|c|c|c|}
\hline Soil parameter (unit) & $\begin{array}{l}\text { Forest } \\
\text { Mean }( \pm S D)\end{array}$ & $\begin{array}{l}\text { Jhum } \\
\text { Mean }( \pm S D)\end{array}$ & $\begin{array}{l}\text { Fallow jhum } \\
\text { Mean ( } \pm \text { SD) }\end{array}$ \\
\hline $\mathrm{BD}\left(\mathrm{Mgm}^{-3}\right)$ & $1.02( \pm 0.13)$ & $1.06( \pm 0.11)$ & $0.89( \pm 0.08)$ \\
\hline Silt (\%) & $25.7( \pm 5.32) \mathrm{a}$ & $31.7( \pm 6.84) \mathrm{a}$ & $42.7( \pm 8.26) \mathrm{b}$ \\
\hline Clay (\%) & $27.0( \pm 10.89)$ & $21.8( \pm 8.72)$ & $14.7( \pm 6.54)$ \\
\hline Sand (\%) & $47.1( \pm 15.45)$ & $46.3( \pm 9.97)$ & $42.5( \pm 14.19)$ \\
\hline Porosity (\%) & $61.5( \pm 5.00)$ & $59.8( \pm 4.27)$ & $66.2( \pm 3.30)$ \\
\hline $\mathrm{pH}(1: 2)$ & $5.26( \pm 0.49)$ & $5.93( \pm 0.63)$ & $5.13( \pm 0.69)$ \\
\hline SOC (\%) & $1.2( \pm 0.54)$ & $1.0( \pm 0.35)$ & $1.6( \pm 1.09)$ \\
\hline Exch. Ca $\left(\mathrm{cmol}(\mathrm{p}+) \mathrm{kg}^{-1}\right)$ & $1.69( \pm 0.82)$ & $1.45( \pm 0.29)$ & $1.67( \pm 1.06)$ \\
\hline Exch. $\operatorname{Mg}\left(\mathrm{cmol}(\mathrm{p}+) \mathrm{kg}^{-1}\right)$ & $0.87( \pm 1.02)$ & $1.61( \pm 1.04)$ & $2.11( \pm 0.0 .76)$ \\
\hline Exch. $\mathrm{Na}\left(\mathrm{cmol}(\mathrm{p}+) \mathrm{kg}^{-1}\right)$ & $0.70( \pm 0.14)$ & $0.85( \pm 0.11)$ & $0.58( \pm 0.0 .24)$ \\
\hline Exch. K (cmol $\left.(\mathrm{p}+) \mathrm{kg}^{-1}\right)$ & $0.93( \pm 1.02)$ & $0.83( \pm 0.34)$ & $0.75( \pm 0.25)$ \\
\hline $\operatorname{CEC}\left(\mathrm{cmol}(\mathrm{p}+) \mathrm{kg}^{-1}\right)$ & $5.39( \pm 2.97)$ & $4.46( \pm 1.88)$ & $3.93( \pm 1.37)$ \\
\hline $\mathrm{Ca} / \mathrm{Mg}$ & $1.87( \pm 1.24)$ & $1.14( \pm 0.48)$ & $0.93( \pm 0.0 .47)$ \\
\hline Av. N $\left(\mathrm{kg} \mathrm{ha}^{-1}\right)$ & $423.71( \pm 58.15)$ & $359.40( \pm 46.65)$ & $408.03( \pm 138.62)$ \\
\hline Av. P $\left(\mathrm{kg} \mathrm{ha} a^{-1}\right)$ & $26.80( \pm 1.96)$ & $27.96( \pm 6.92)$ & $26.07( \pm 1.65)$ \\
\hline Av. $\mathrm{K}\left(\mathrm{kg} \mathrm{ha}^{-1}\right)$ & $256.16( \pm 53.00)$ & $221.62( \pm 22.28)$ & $244.27( \pm 11.94)$ \\
\hline
\end{tabular}

$a$ and $b$ indicate significant differences $(\mathrm{P}<0.05)$ among different land uses. BD: Bilk density; SOC: Soil Organic Carbon; Exch. Ca: Exchangeable Calcium; Exch. Mg: Exchangeable Magnesium; Exch. Na: Exchangeable Sodium; Exch. K: Exchangeable Potassium; CEC: Cation Exchange Capacity; BS: Base Saturation; Av. N: Available Nitrogen; Av. P: Available Phosphorus; Av. K: Available Potassium 
However, the results of ANOVA indicated that soil properties did not vary significantly $(p<0.05)$ among the land uses, except for silt particles $(F=6.198, p=0.020)$. To confirm that, we used the coefficient of variation $(\mathrm{CV})$ to assess the variability of soil properties in each land use. Clay, SOC, CEC, BS, and $\mathrm{Ca} / \mathrm{Mg}$ register the highest variability $(\mathrm{CV}>35 \%)$ in all three land-use types. In jhum fallow land, all the exchangeable cations ( $\mathrm{Ca}, \mathrm{Mg}, \mathrm{Na}$, and $\mathrm{K}$ ) highly change, whereas, in forest land, $\mathrm{Ca}$ and $\mathrm{K}$ show a higher variability among exchangeable cations. Moreover, the variation is low $(\mathrm{CV}<0.15 \%)$ for $\mathrm{BD}$, porosity, and $\mathrm{pH}$ in all the land uses.

\subsection{Principal component analysis}

The results of PCA for the forest, jhum and fallow jhum are presented in table 3, 4 and 5, respectively. In the forest, five PCs explained 85\% of the total variance (Table 3). In PC 1, BD (-0.93), porosity (0.93) and exchangeable $\mathrm{Mg}(0.86)$ are the highest weighted properties. Among them, BD can be selected as an indicator of correlation among the highly weighed properties indicate that they are highly and significantly correlated. In PC 2, clay (0.93), sand (-0.95), and BS (0.79) were highly weighed and after correlation (Supplementary information Table S2) and is retained in MDS. Similarly, in PC 3, pH (-0.74), SOC (0.75), Ca: Mg (-0.74) and Nav (0.77) are highly weighed, but only Nav is included in MDS after they are found to be highly correlated. However, in PC 4 and PC 5, only exchangeable $\mathrm{Na}(0.91)$ and Pav (0.99) are highly weighed and hence retained in MDS. Thus, BD, sand, Nav, Exch. Na and Pav are the five soil quality indicators selected for evaluating soil quality under forest.

Table 3. Result of principal components, eigenvalues and component matrix variables of forest sites

\begin{tabular}{|c|c|c|c|c|c|}
\hline Principal components & $\mathrm{PC} 1$ & PC2 & PC3 & PC4 & PC5 \\
\hline Eigen values & 5.4 & 3.1 & 2.6 & 2.0 & 1.0 \\
\hline$\%$ variance & 32.3 & 18.0 & 15.8 & 11.7 & 6.0 \\
\hline$\%$ Cumulative variance & 32.3 & 51.1 & 66.9 & 78.7 & 84.7 \\
\hline Weightage factor & 0.38 & 0.22 & 0.19 & 0.14 & 0.07 \\
\hline \multicolumn{6}{|c|}{ Factor loadings (Rotated component matrix) } \\
\hline $\mathrm{BD}$ & $-0.93^{*}$ & -0.00 & -0.20 & 0.17 & 0.06 \\
\hline Silt & 0.02 & 0.65 & 0.23 & -0.48 & 0.09 \\
\hline Clay & 0.08 & 0.93 & 0.16 & 0.04 & 0.02 \\
\hline Sand & -0.07 & $-0.95^{*}$ & -0.20 & 0.16 & -0.05 \\
\hline porosity & 0.93 & 0.00 & 0.20 & -0.17 & -0.06 \\
\hline $\mathrm{pH}$ & 0.02 & -0.10 & -0.74 & -0.05 & -0.08 \\
\hline SOC & 0.43 & 0.09 & 0.75 & 0.37 & 0.03 \\
\hline CEC & 0.65 & 0.03 & 0.30 & 0.49 & -0.03 \\
\hline Exch. Ca. & -0.65 & 0.03 & 0.06 & -0.34 & 0.40 \\
\hline Exch. Mg. & -0.86 & -0.21 & 0.26 & -0.12 & 0.13 \\
\hline Ca:Mg & 0.45 & -0.05 & -0.74 & 0.34 & 0.16 \\
\hline Exch. Na. & -0.06 & -0.02 & 0.12 & $0.91 *$ & 0.03 \\
\hline Exch. K. & 0.28 & 0.69 & -0.11 & 0.58 & -0.12 \\
\hline BS & -0.10 & 0.79 & -0.21 & 0.44 & -0.16 \\
\hline Av. N & 0.27 & 0.07 & $0.77^{*}$ & 0.03 & 0.10 \\
\hline Av. P & -0.19 & -0.01 & 0.08 & 0.02 & $0.92 *$ \\
\hline Av. K & 0.61 & 0.42 & 0.15 & 0.48 & 0.18 \\
\hline
\end{tabular}

*: factors identified as the indicators retained in the Minimum Data Set. PC: Principal components; BD: Bilk density; SOC: Soil Organic Carbon; Exch. Ca: Exchangeable Calcium; Exch. Mg: Exchangeable Magnesium; Exch. Na: Exchangeable Sodium; Exch. K: Exchangeable Potassium; CEC: Cation Exchange Capacity; BS: Base Saturation; Av. N: Available Nitrogen; Av. P: Available Phosphorus; Av. K: Available Potassium

Own elaboration

In the jhum land, five PCs explained $87.6 \%$ of the total variability. In PC $1, \mathrm{BD}(-0.915)$, porosity (0.91), SOC (0.84), Ex. Mg (-0.77) and BS (0.90) were highly weighed properties (Table 4). The correlation among them indicate a significant relationship, hence, only BD is selected as an SQ indicator. From PC 2, sand (-0.80), silt (-0.78) and $\mathrm{Ca} / \mathrm{Mg}(0.78)$ is selected and after the correlation analysis, sand is 
retained in MDS. In PC 3, clay (0.82) and Kav (0.84) are highly weighted but, only Kav is chosen for MDS because of its relatively higher loading factor than clay. However, in PC 4 and PC 5, only exchangeable $\mathrm{Ca}(0.80)$ and $\mathrm{Na}(0.75)$ are highly weighted and retained in MDS. Thus, BD, sand, Kav, Exch. Ca and $\mathrm{Na}$ are selected in MDS for soil quality evaluation of the jhum land.

Table 4. Result of Principal components, eigenvalues and component matrix variables of Jhum sites

\begin{tabular}{lccccc}
\hline Principal components & PC1 & PC2 & PC3 & PC4 & PC5 \\
\hline Eigen values & 7.0 & 2.8 & 2.5 & 1.3 & 1.1 \\
\% variance & 41.4 & 16.7 & 14.7 & 8.0 & 6.6 \\
\% Cumulative variance & 41.4 & 58.1 & 72.9 & 80.9 & 87.6 \\
\hline Weightage factor & 0.4 & 0.1 & 0.1 & 0.0 & 0.0 \\
\hline \multicolumn{5}{c}{ Factor loadings (Rotated component matrix) } \\
BD & $-0.91^{*}$ & -0.05 & -0.10 & -0.26 & -0.18 \\
Silt & 0.04 & -0.78 & -0.36 & 0.31 & -0.10 \\
Clay & -0.34 & -0.13 & 0.82 & -0.35 & -0.16 \\
Sand & 0.24 & $0.80^{*}$ & -0.36 & 0.02 & 0.22 \\
porosity & 0.91 & 0.05 & 0.10 & 0.26 & 0.18 \\
pH & 0.25 & 0.35 & -0.12 & 0.65 & 0.40 \\
SOC & 0.84 & -0.10 & 0.24 & -0.03 & -0.15 \\
CEC & 0.70 & 0.55 & -0.12 & 0.18 & 0.12 \\
Exch. Ca. & 0.03 & 0.15 & 0.27 & $-0.80^{*}$ & -0.09 \\
Exch. Mg. & -0.77 & -0.31 & 0.41 & -0.13 & -0.17 \\
Ca:Mg & 0.30 & 0.78 & -0.22 & 0.33 & -0.18 \\
Exch. Na. & 0.11 & 0.11 & -0.06 & 0.07 & $0.95^{*}$ \\
Exch. K. & -0.27 & 0.71 & 0.29 & 0.32 & 0.32 \\
BS & -0.90 & -0.04 & 0.32 & 0.10 & -0.02 \\
Av. N & 0.37 & 0.34 & -0.09 & 0.65 & -0.19 \\
Av. P & -0.68 & -0.49 & 0.00 & -0.07 & 0.18 \\
Av. K & 0.45 & 0.09 & $0.84^{*}$ & -0.19 & 0.05 \\
\hline
\end{tabular}

*: factor loadings considered highly weighed; asterisk: factors identified as the indicators retained in the Minimum Data Set. PC: Principal components; BD: Bilk density; SOC: Soil Organic Carbon; Exch. Ca: Exchangeable Calcium; Exch. Mg: Exchangeable Magnesium; Exch. Na: Exchangeable Sodium; Exch. K: Exchangeable Potassium; CEC: Cation Exchange Capacity; BS: Base Saturation; Av. N: Available Nitrogen; Av. P: Available Phosphorus; Av. K: Available Potassium

\section{Own elaboration}

In the fallow jhum lands, four PCs can explain $88 \%$ of the variability (Table 5). In PC 1, BD, porosity, Exch, Mg, and Kav are considered as highly weighed properties. Among them, BD is retained in MDS, showing after the correlation analysis a significant relationship. In PC 2, Exch. $\mathrm{Ca}, \mathrm{Na}, \mathrm{Ca} / \mathrm{Mg}$, and $\mathrm{Nav}$ is the selected properties. After observing the correlation results, Nav is only the selected variable. In PC 3, clay, Exch. K and BS are the most interrelated properties, but only clay is used in MDS. Finally, in PC 4, silt is the only highly weighed property, therefore, and it is also selected. Thus, BD, silt, clay and Nav are selected as soil quality indicators for the jhum fallow land.

Table 5. Result of Principal components, eigenvalues and component matrix variables of fallow jhum sites

\begin{tabular}{lcccc}
\hline \multicolumn{1}{c}{ Principal components } & PC1 & PC2 & PC3 & PC4 \\
\hline Eigen values & 5.1 & 4.6 & 3.3 & 1.8 \\
\% variance & 30.5 & 27.2 & 19.6 & 10.8 \\
\% Cumulative variance & 30.5 & 57.8 & 77.4 & 88.3 \\
\hline Weightage factor & 0.3 & 0.3 & 0.2 & 0.1 \\
\hline \multicolumn{4}{r}{ Factor loadings (Rotated component matrix) } \\
BD & $-0.89^{*}$ & -0.15 & 0.33 & -0.03 \\
Silt & -0.12 & -0.04 & -0.01 & $-0.95^{*}$ \\
Clay & -0.11 & 0.14 & $0.90^{*}$ & 0.05
\end{tabular}




\begin{tabular}{lrrrr} 
Sand & 0.17 & -0.07 & -0.64 & 0.68 \\
porosity & 0.89 & 0.15 & -0.33 & 0.03 \\
pH & -0.48 & -0.71 & -0.27 & 0.22 \\
SOC & 0.66 & 0.67 & -0.24 & 0.17 \\
CEC & 0.57 & 0.09 & -0.53 & 0.37 \\
Exch. Ca. & 0.20 & 0.88 & 0.16 & 0.26 \\
Exch. Mg. & 0.75 & 0.05 & 0.43 & 0.43 \\
Ca:Mg & -0.34 & 0.87 & -0.16 & 0.00 \\
Exch. Na. & 0.22 & 0.77 & 0.43 & -0.35 \\
Exch. K. & -0.05 & 0.12 & -0.82 & 0.41 \\
BS & -0.03 & 0.37 & 0.80 & 0.08 \\
Av. N & 0.07 & $-0.91^{*}$ & -0.10 & -0.09 \\
Av. P & 0.60 & -0.15 & 0.17 & -0.58 \\
Av. K & 0.75 & -0.33 & 0.38 & -0.08 \\
\hline
\end{tabular}

*: factor loadings considered highly weighed; asterisk: factors identified as the indicators retained in the Minimum Data Set. PC: Principal components; BD: Bilk density; SOC: Soil Organic Carbon; Exch. Ca: Exchangeable Calcium; Exch. Mg: Exchangeable Magnesium; Exch. Na: Exchangeable Sodium; Exch. K: Exchangeable Potassium; CEC: Cation Exchange Capacity; BS: Base Saturation; Av. N: Available Nitrogen; Av. P: Available Phosphorus; Av. K: Available Potassium

Own elaboration

\subsection{Soil quality under different land uses}

Additive and weighted SQIs (Table 6) for the soils in the three different land-use types are calculated to find out the impact of land uses on soil quality. For the surface soil layer, additive SQI shows the highest values as follows: jhum $>$ forest $>$ fallow jhum. For the subsurface soil $(30-70 \mathrm{~cm})$, the same trend is also observed. The weighted SQI of all the three-land use also follows the same trend as additive SQI. Moreover, in both additive and weighted index methods, the SQIs are similar for both surface and subsurface soils. In the surface soil, the mean value of both SQI is significantly different for three land uses. Jhum soils obtain the highest SQIs (3.90 and 0.78), followed by the forest (3.34 and 0.68) and fallow jhum (2.61 and 0.66). Similarly, mean SQI values significantly vary for surface and subsurface soil layers, but SQIs are not significantly different for the forest and jhum. However, fallow jhum has the lowest value of SQIs.

Table 6. Soil quality index (SQI) values for different land uses sites at two depths

\begin{tabular}{|c|c|c|c|c|c|c|c|c|c|}
\hline \multirow{3}{*}{ Parameters } & \multirow{3}{*}{ ID } & \multirow{2}{*}{\multicolumn{2}{|c|}{$\begin{array}{c}\text { Forest } \\
\text { Depth }(\mathrm{cm})\end{array}$}} & \multirow{2}{*}{\multicolumn{3}{|c|}{$\begin{array}{c}\text { Jhum } \\
\text { Depth }(\mathrm{cm})\end{array}$}} & \multirow{3}{*}{ ID } & \multirow{2}{*}{\multicolumn{2}{|c|}{$\begin{array}{l}\text { Fallow jhum } \\
\text { Depth }(\mathrm{cm})\end{array}$}} \\
\hline & & & & & & & & & \\
\hline & & $0-30$ & $30-70$ & ID & $0-30$ & $30-70$ & & $0-30$ & $30-70$ \\
\hline \multirow{6}{*}{ Additive index } & FSl & 3.27 & 3.48 & Jhl & 4.15 & 3.97 & Fjhl & 2.46 & 2.55 \\
\hline & FS2 & 3.14 & 3.02 & Jh2 & 3.68 & 3.54 & Fjh2 & 2.45 & 2.28 \\
\hline & FS3 & 3.55 & 3.63 & Jh3 & 3.67 & 3.75 & Fjh3 & 2.90 & 3.11 \\
\hline & FS4 & 3.15 & 3.44 & Jh4 & 4.07 & 3.94 & - & - & - \\
\hline & FS5 & 3.59 & 3.51 & - & - & - & - & - & - \\
\hline & $\begin{array}{l}\text { Mean } \\
( \pm S D)\end{array}$ & $\begin{array}{c}3.34 \\
( \pm 0.21) b\end{array}$ & $\begin{array}{c}3.42 \\
( \pm 0.23) \mathrm{b}\end{array}$ & $\begin{array}{l}\text { Mean } \\
( \pm \text { SD })\end{array}$ & $\begin{array}{c}3.90 \\
( \pm 0.25) c\end{array}$ & $\begin{array}{c}3.80 \\
( \pm 0.19) b\end{array}$ & $\begin{array}{l}\text { Mean } \\
( \pm S D)\end{array}$ & $\begin{array}{c}2.61 \\
( \pm 0.25) a\end{array}$ & $\begin{array}{c}2.64 \\
( \pm 0.42) a\end{array}$ \\
\hline \multirow{6}{*}{$\begin{array}{l}\text { Weighted } \\
\text { index }\end{array}$} & FSl & 0.66 & 0.71 & Jhl & 0.82 & 0.81 & Fjhl & 0.67 & 0.68 \\
\hline & FS2 & 0.65 & 0.63 & Jh2 & 0.76 & 0.74 & Fjh2 & 0.62 & 0.58 \\
\hline & FS3 & 0.74 & 0.75 & Jh3 & 0.76 & 0.79 & Fjh3 & 0.70 & 0.77 \\
\hline & FS4 & 0.70 & 0.76 & Jh4 & 0.79 & 0.78 & - & - & - \\
\hline & FS5 & 0.69 & 0.69 & - & - & - & - & - & - \\
\hline & $\begin{array}{l}\text { Mean } \\
( \pm \text { SD })\end{array}$ & $\begin{array}{c}0.68 \\
( \pm 0.03) \mathrm{a}\end{array}$ & $\begin{array}{c}0.70 \\
( \pm 0.05) \mathrm{ab}\end{array}$ & $\begin{array}{l}\text { Mean } \\
( \pm \text { SD })\end{array}$ & $\begin{array}{c}0.78 \\
( \pm 0.02) b\end{array}$ & $\begin{array}{c}0.78 \\
( \pm 0.02) b\end{array}$ & $\begin{array}{l}\text { Mean } \\
( \pm S D)\end{array}$ & $\begin{array}{c}0.66 \\
( \pm 0.04) a\end{array}$ & $\begin{array}{c}0.67 \\
( \pm 0.09) a\end{array}$ \\
\hline
\end{tabular}

${ }^{*}$ For site labels see Table 1 


\section{Discussion}

\subsection{Soil quality indicators}

The soil physicochemical properties under three different land uses were evaluated for their capability to serve as potential indicators for monitoring soil quality changes due to shifting cultivation in the NEH region of India. Firstly, it is important to remark that we recorded the highest mean value of BD in jhum lands, followed by forest and fallows jhum, meanwhile, a reverse trend was observed for SOC content. These results were consistent with the findings of Sharma, Gairola, Ghildiyal, \& Suyal (2010) who reported that $\mathrm{BD}$ and organic $C$ were negatively correlated $(-0.45)$ in soils of western Himalayas. Moreover, it is a well-established fact that BD and C are inversely proportional to each other (Post \& Kwon, 2000; Pulido, Schnabel, Lavado-Contador, Miralles Mellado, Ortega \& Pérez, 2013), as the lower value of BD in the soil is an indicator of higher SOM content and good aeration (NRC, 1981). Leskiw (1998) also reported that forest soils should be slightly acidic for proper nutrient supply. Similarly, soils under forest areas in our study were acidic to slightly acidic as compared to other land use. The variation observed in clay, SOC, Exch. cations and CEC under the studied land uses may be attributed to a combination of intrinsic factors such as weathering, erosion, deposition, and soil-forming processes and extrinsic ones such as management practices (Pulido et al., 2020; Vasu et al., 2016).

As many as twenty-one soil properties were suggested as potential indicators for soil quality evaluation under different ecosystems by earlier studies (Askari \&Holden, 2015). However, the use of PCA showed to be a useful tool to reduce the possible number of variables. In this way, it is important to remark that the BD was repeated as MDS for all the land uses, indicating its effectiveness as an indicator for soil quality monitoring in the jhum cultivation system. The importance of BD as an SQ indicator was also indicated by Askari \&Holden (2015) in their study in the grassland of Ireland, coinciding with other authors, because it plays an important role in the regulation of water transmission (Rawls et al., 1998) and root penetration (Pierce, Larson, Dowdy, \& Graham1983). The values of BD in the forest and fallow jhum were lower than the jhum lands and it generally increased according to the depth. Generally, BD increases with profile depth, due to the variation in organic matter content, porosity and compaction (Askin \&Ozdemir, 2003; Chaudhari, Ahire, Ahire, Chkravarty, \& Maity, 2013).

Soil texture was also reported as an important soil quality indicator in earlier studies (Brejda \&Moorman, 2001; Cho, Zoebisch \& Ranamukhaarachchi, 2004; Shukla, Lal, \& Ebinger2006). Our results were also consistent with these earlier studies, as sand was obtained for the forest and jhum as soil quality indicator, meanwhile, clay and silt were indicators for fallow jhum. Recently, Vinhal-Freitasa, Correa, Wendling, Bobul'skác, \& Ferreira. (2017) also reported the importance of soil textural classes in evaluating the soil functions and their quality, specifically, in tropical ecosystems like in our study area. The variation in textural classes among land uses was also reported in our study. According to Rao \&Wagenet (1985), differences in clay content along the soil profile depth is the result of weathering, erosion, deposition, and soil-forming processes. In our case, possibly, this kind of variation can be also generated by these processes regarding the total rainfall and high mean temperatures.

In the current study, macronutrients (Nav and Pav) were obtained as the soil indicators for forest sites, while in jhum areas only Kav was selected as an SQ indicator. The significance of macronutrients in MDS can be attributed to their importance in sustaining plant productivity and soil fertility. As in this study, Kav and Nav were also selected as SQ indicators for restoration of degraded lands in the alpine region of the Qinghai-Tibetan Plateau of China (Dong et al., 2012). In jhum lands, Exch. Ca2+ and $\mathrm{Na}+$ were also considered in PCA, while Na+ was selected for forest sites. Soil chemical properties, like CEC (Khaledian et al., 2017) and extractable anion and cations have been used as effective chemical indicators of soil quality. In most of the sites, the value of CEC was found to be decreasing with depth. These results are in the line with the findings of Khan and Kamalkar (2012), who reported that in upland soils, the values of CEC decrease with depth, due to its correspondence with the clay content (Bhaskar, Butte\& UtpalBrauah,2005).

\subsection{Effect of land use on SQI}

Deriving SQI from a concrete number of parameters, using PCA and MDS, was demonstrated as a useful approach to evaluate the sustainability of land use. The quality of the studied soils was influenced by land use and soil layers. In the surface layer $(0-30 \mathrm{~cm})$, jhum land soils show better SQIs in comparison to the forest and fallow jhum. A higher value of additive and weighted SQI in jhum lands can be supported 
by the fact that before the cultivation, vegetation was slashed and burned in fields, which increases the availability of nutrients (P, K, Ca and Mg) (Lungmuanaa et al., 2017) and results in a better fertility status in surface layers. Moreover, the ash of burned biomass releases alkaline cations which help in maintaining neutral pH level and the availability of soil nutrients (Dikici \&Yilmaz, 2006). But as Granged, Zavala, Jordan\& Moreno(2011) observed, these effects were short-term (8-12 months).

The relatively better quality of soils under shifting cultivation was also reported by other abovementioned authors. However, this improved status of nutrients can decline in subsequent years, due to cultivation, leaching, runoff and soil erosion as registered by other authors in Mizoram state of India (Tawnenga, Shankar\& Tripathi, 1997). The slightly lower value of SQI in the forest sites in comparison to the jhum ones can be supported by the fact that much of the nutrient reserve of tropical forests is stored in plant tissue but critical nutrient limitation will occur if biomass is removed (Dalling, Heineman, Lopez, Wright, \& Turner2016). A lower value of additive and weighted SQI in fallow jhum lands may be attributed to the fast growth of the second successive vegetation during the fallow period. In the fallow jhum lands, a soil recovery process takes place and over the years, organic matter, $\mathrm{N}$, and CEC can increase (MendozaVega \&Messing, 2005). Also, the age of vegetation (shrub and perennial grass species) can determine the magnitude of the improvement in soil quality as Caravaca et al. (2003) observed in of Murcia Province of southeastern Spain. Our findings indicate that the conversion of forests into jhum lands will not hamper the soil quality in NEH. But the cultivation in subsequent years can make the soil more prone to erosion, compaction, degradation of physical attributes, SOC loss, and reduction in nutrient availability, which will go to reduce soil quality.

Finally, we can highlight some issues related to our consideration of analyzing our results separately instead of all together. Firstly, we considered that it is vital to compare three types of land uses, although inside each type of use we obtained by PCA high eigenvalues for PC1-5. The main goal was to find variables to distinguish sites as much as possible inside each type of use instead of between different type of use as it is common. To confirm with another method our hypothesis, we also use the SQI. In the future, we will consider the use of the whole data set (including all three types of use) to look for eigenvalues with lower values. Secondly, it would be interesting to use one dimension and not complexity data for modifying the application of the PCA in this study. The initial data matrix could be transformed. One possibility could be the centered log-ratio transformation to the working matrix $\operatorname{clr}(\mathrm{x})$ as it was developed by Kholodov et al. (2019) according to the equation: $\operatorname{clr}(\mathrm{x})=[\log \{\mathrm{x} l / g(\mathrm{x})\}, \ldots . \log \{\mathrm{xi} / \mathrm{g}(\mathrm{x})\}]$, where $\mathrm{x}$ would denote the initial data, and $\mathrm{g}(\mathrm{x})$ their geometric mean. Perhaps because the matrix transformation was not carried out our results were based on specific agronomic factors such as $\mathrm{BD}$ with one of the smallest variation coefficient.

\section{Conclusions}

We identified that BD, soil texture, Nav, Pav, Kav, Exch. Ca and $\mathrm{Na}$ is the major indicators of soil quality in NEH, India. The use of these selected indicators in soil quality assessment was really useful in terms of reduction in analysis cost and time. The study indicated that surface layers of forests soils have a lower soil quality when compared to the jhum lands. Although the jhum lands show a better soil quality compared to forests, their continued cultivation without fertilization and subsequent depletion of the soil nutrients can cause a degradation of soil quality as observed in the fallow jhum lands. However, further studies, including some biological indicators such as enzyme activities and microbial counts would be needed to better understand the complexity of shifting cultivation and to assess the soil functions in the studied region and design effective and correct land use management plans.

\section{Acknowledgements}

We thank all the staff of Rain Forest Research Institute, Jorhat, Assam, who was knowingly or unknowingly provided their help, support and cooperation in completing the study. This research was funded by the Indian Council of Forestry Research and Education (ICFRE), Dehradun, India. The authors gratefully thank the anonymous reviewers and the editors whose valuable suggestions and comments have helped enrich the quality of this article. 


\section{Appendix}

Appendix 1. Descriptive statistics of soil properties used for soil quality assessment in forest areas

\begin{tabular}{|c|c|c|c|c|c|c|}
\hline Variable (unit) & Min & $\operatorname{Max}$ & Mean & Std. dev & $\mathrm{CV}$ & Skewness \\
\hline $\mathrm{BD}\left(\mathrm{Mgm}^{-3}\right)$ & 0.76 & 1.31 & 1.03 & 0.13 & 0.12 & 0.43 \\
\hline Silt (\%) & 18.1 & 38.2 & 26.4 & 6.0 & 0.2 & 0.6 \\
\hline Clay (\%) & 15.0 & 53.3 & 28.2 & 1.3 & 0.4 & 0.6 \\
\hline Sand (\%) & 21.8 & 66.2 & 45.2 & 15.2 & 0.3 & -0.0 \\
\hline Porosity (\%) & 50.7 & 71.3 & 61.3 & 4.7 & 0.0 & -0.4 \\
\hline $\mathrm{pH}(1: 2)$ & 3.56 & 6.25 & 5.29 & 0.60 & 0.11 & -1.17 \\
\hline SOC (\%) & 0.4 & 3.1 & 1.1 & 0.6 & 0.6 & 1.5 \\
\hline Exch. Ca $\left(\mathrm{cmol}(\mathrm{p}+) \mathrm{kg}^{-1}\right)$ & 0.71 & 3.70 & 1.74 & 0.88 & 0.50 & 0.99 \\
\hline Exch. $\mathrm{Mg}\left(\mathrm{cmol}(\mathrm{p}+) \mathrm{kg}^{-1}\right)$ & 0.25 & 3.38 & 1.87 & 0.80 & 0.66 & 1.33 \\
\hline Exch. $\mathrm{Na}\left(\mathrm{cmol}(\mathrm{p}+) \mathrm{kg}^{-1}\right)$ & 0.36 & 0.93 & 0.70 & 0.18 & 0.26 & -0.56 \\
\hline Exch. K $\left(\mathrm{cmol}(\mathrm{p}+) \mathrm{kg}^{-1}\right)$ & 0.27 & 3.07 & 1.00 & 1.03 & 1.03 & 1.32 \\
\hline $\operatorname{CEC}\left(\mathrm{cmol}(\mathrm{p}+) \mathrm{kg}^{-1}\right)$ & 1.79 & 16.29 & 5.19 & 3.57 & 0.69 & 1.78 \\
\hline BS (\%) & 7.1 & 58.3 & 21.1 & 12.4 & 0.6 & 1.6 \\
\hline $\mathrm{Ca} / \mathrm{Mg}$ & 0.65 & 5.21 & 1.87 & 1.24 & 0.66 & 1.55 \\
\hline Av. N $\left(\mathrm{kg} \mathrm{ha}^{-1}\right)$ & 224.00 & 638.62 & 418.68 & 97.70 & 0.23 & 0.11 \\
\hline Av. P $\left(\mathrm{kg} \mathrm{ha}^{-1}\right)$ & 19.68 & 38.50 & 27.02 & 4.69 & 0.17 & 0.90 \\
\hline Av. K $\left(\mathrm{kg} \mathrm{ha}^{-1}\right)$ & 112.00 & 336.00 & 256.65 & 67.44 & 0.26 & -0.35 \\
\hline
\end{tabular}

BD: Bulk density; SOC: Soil Organic Carbon; Exch. Ca: Exchangeable Calcium; Exch. Mg: Exchangeable Magnesium; Exch. Na: Exchangeable Sodium; Exch. K: Exchangeable Potassium; CEC: Cation Exchange Capacity; BS: Base Saturation; Av. N: Available Nitrogen; Av. P: Available Phosphorus; Av. K: Available Potassium

$$
\text { Own elaboration }
$$

Appendix 2. Descriptive statistics of soil properties used for soil quality assessment in jhum land

\begin{tabular}{|c|c|c|c|c|c|c|}
\hline Variable & Min & Max & Mean & Std. dev & $\mathrm{CV}$ & Skewness \\
\hline $\mathrm{BD}\left(\mathrm{Mg} \mathrm{m}^{-3}\right)$ & 0.93 & 1.32 & 1.06 & 0.11 & 0.11 & 1.27 \\
\hline Silt (\%) & 18.5 & 49.6 & 31.7 & 10.0 & 0.3 & 0.5 \\
\hline Clay (\%) & 6.7 & 41.0 & 21.8 & 9.4 & 0.4 & 0.1 \\
\hline Sand (\%) & 26.5 & 63.5 & 46.3 & 11.3 & 0.2 & -0.1 \\
\hline Porosity (\%) & 50.1 & 64.9 & 59.8 & 4.2 & 0.0 & -1.2 \\
\hline $\mathrm{pH}(1: 2)$ & 4.55 & 7.05 & 5.9 & 0.73 & 0.12 & 0.11 \\
\hline SOC (\%) & 0.4 & 1.6 & 1.0 & 0.4 & 0.4 & -0.0 \\
\hline Exch. Ca $\left(\mathrm{cmol}(\mathrm{p}+) \mathrm{kg}^{-1}\right)$ & 0.99 & 2.19 & 1.46 & 0.37 & 0.25 & 0.89 \\
\hline Exch. $\mathrm{Mg}\left(\mathrm{cmol}(\mathrm{p}+) \mathrm{kg}^{-1}\right)$ & 0.72 & 4.40 & 1.61 & 1.04 & 0.42 & 1.81 \\
\hline Exch. $\mathrm{Na}\left(\mathrm{cmol}(\mathrm{p}+) \mathrm{kg}^{-1}\right)$ & 0.61 & 1.72 & 0.85 & 0.26 & 0.30 & 2.84 \\
\hline Exch. K $\left(\mathrm{cmol}(\mathrm{p}+) \mathrm{kg}^{-1}\right)$ & 0.38 & 1.64 & 0.84 & 0.37 & 0.45 & 0.86 \\
\hline $\operatorname{CEC}\left(\mathrm{cmol}(\mathrm{p}+) \mathrm{kg}^{-1}\right)$ & 1.75 & 7.26 & 4.46 & 1.90 & 0.43 & 0.10 \\
\hline BS (\%) & 8.6 & 55.6 & 25.2 & 14.9 & 0.5 & 0.9 \\
\hline $\mathrm{Ca} / \mathrm{Mg}$ & 0.31 & 1.65 & 1.14 & 0.48 & 0.42 & -0.52 \\
\hline Av. $N\left(\mathrm{~kg} \mathrm{ha}^{-1}\right)$ & 246.40 & 456.96 & 359.39 & 63.51 & 0.18 & -0.32 \\
\hline Av. P $\left(\mathrm{kg} \mathrm{ha}^{-1}\right)$ & 11.54 & 38.90 & 27.96 & 7.14 & 0.26 & -0.55 \\
\hline Av. $\mathrm{K}\left(\mathrm{kg} \mathrm{ha}^{-1}\right)$ & 168.80 & 272.00 & 221.63 & 29.78 & 0.13 & -0.14 \\
\hline
\end{tabular}

BD: Bulk density; SOC: Soil Organic Carbon; Exch. Ca: Exchangeable Calcium; Exch. Mg: Exchangeable Magnesium; Exch. Na: Exchangeable Sodium; Exch. K: Exchangeable Potassium; CEC: Cation Exchange Capacity; BS: Base Saturation; Av. N: Available Nitrogen; Av. P: Available Phosphorus; Av. K: Available Potassium 
Appendix 3. Descriptive statistics of soil properties used for soil quality assessment in fallow jhum areas

\begin{tabular}{|c|c|c|c|c|c|c|}
\hline Variable & Min & Max & Mean & Std. dev & $\mathrm{CV}$ & Skewness \\
\hline $\mathrm{BD}\left(\mathrm{Mg} \mathrm{m}^{-3}\right)$ & 0.74 & 1.07 & 0.90 & 0.11 & 0.13 & 0.36 \\
\hline Silt (\%) & 26.8 & 59.9 & 42.4 & 9.9 & 0.2 & 0.5 \\
\hline Clay (\%) & 1.6 & 29.2 & 14.2 & 9.3 & 0.6 & 0.3 \\
\hline Sand (\%) & 23.8 & 59.0 & 43.2 & 13.0 & 0.3 & -0.3 \\
\hline Porosity (\%) & 59.5 & 72.2 & 66.2 & 4.3 & 0.0 & -0.3 \\
\hline $\mathrm{pH}(1: 2)$ & 4.22 & 6.08 & 5.19 & 0.66 & 0.13 & 0.00 \\
\hline SOC (\%) & 0.4 & 3.2 & 1.6 & 1.0 & 0.6 & 0.5 \\
\hline Exch. Ca $\left(\mathrm{cmol}(\mathrm{p}+) \mathrm{kg}^{-1}\right)$ & 0.59 & 3.87 & 1.60 & 1.05 & 0.66 & 1.27 \\
\hline Exch. $\mathrm{Mg}\left(\mathrm{cmol}(\mathrm{p}+) \mathrm{kg}^{-1}\right)$ & 1.22 & 6.34 & 2.08 & 1.33 & 0.64 & 3.18 \\
\hline Exch. $\mathrm{Na}\left(\mathrm{cmol}(\mathrm{p}+) \mathrm{kg}^{-1}\right)$ & 0.29 & 0.77 & 0.56 & 0.22 & 0.39 & -0.50 \\
\hline Exch. K $\left(\mathrm{cmol}(\mathrm{p}+) \mathrm{kg}^{-1}\right)$ & 0.34 & 1.32 & 0.76 & 0.28 & 0.37 & 0.11 \\
\hline $\operatorname{CEC}\left(\mathrm{cmol}(\mathrm{p}+) \mathrm{kg}^{-1}\right)$ & 1.97 & 7.20 & 3.97 & 1.63 & 0.41 & 0.62 \\
\hline BS (\%) & 50.6 & 215.6 & 121.6 & 45.1 & 0.3 & 0.4 \\
\hline $\mathrm{Ca} / \mathrm{Mg}$ & 0.28 & 3.17 & 0.90 & 0.76 & 0.85 & 2.52 \\
\hline Av. N $\left(\mathrm{kg} \mathrm{ha}^{-1}\right)$ & 179.20 & 417.69 & 229.76 & 140.49 & 0.34 & -0.14 \\
\hline Av. P $\left(\mathrm{kg} \mathrm{ha}^{-1}\right)$ & 19.26 & 29.79 & 25.94 & 3.50 & 0.13 & -0.65 \\
\hline Av. K $\left(\mathrm{kg} \mathrm{ha}^{-1}\right)$ & 144.00 & 347.00 & 243.57 & 53.05 & 0.22 & -0.04 \\
\hline
\end{tabular}

BD: Bulk density; SOC: Soil Organic Carbon; Exch. Ca: Exchangeable Calcium; Exch. Mg: Exchangeable Magnesium; Exch. Na: Exchangeable Sodium; Exch. K: Exchangeable Potassium; CEC: Cation Exchange Capacity; BS: Base Saturation; Av. N: Available Nitrogen; Av. P: Available Phosphorus; Av. K: Available Potassium

Own elaboration

Appendix 4. Depth-wise distribution of soil indicators selected after principal component analysis for each profile under Forests
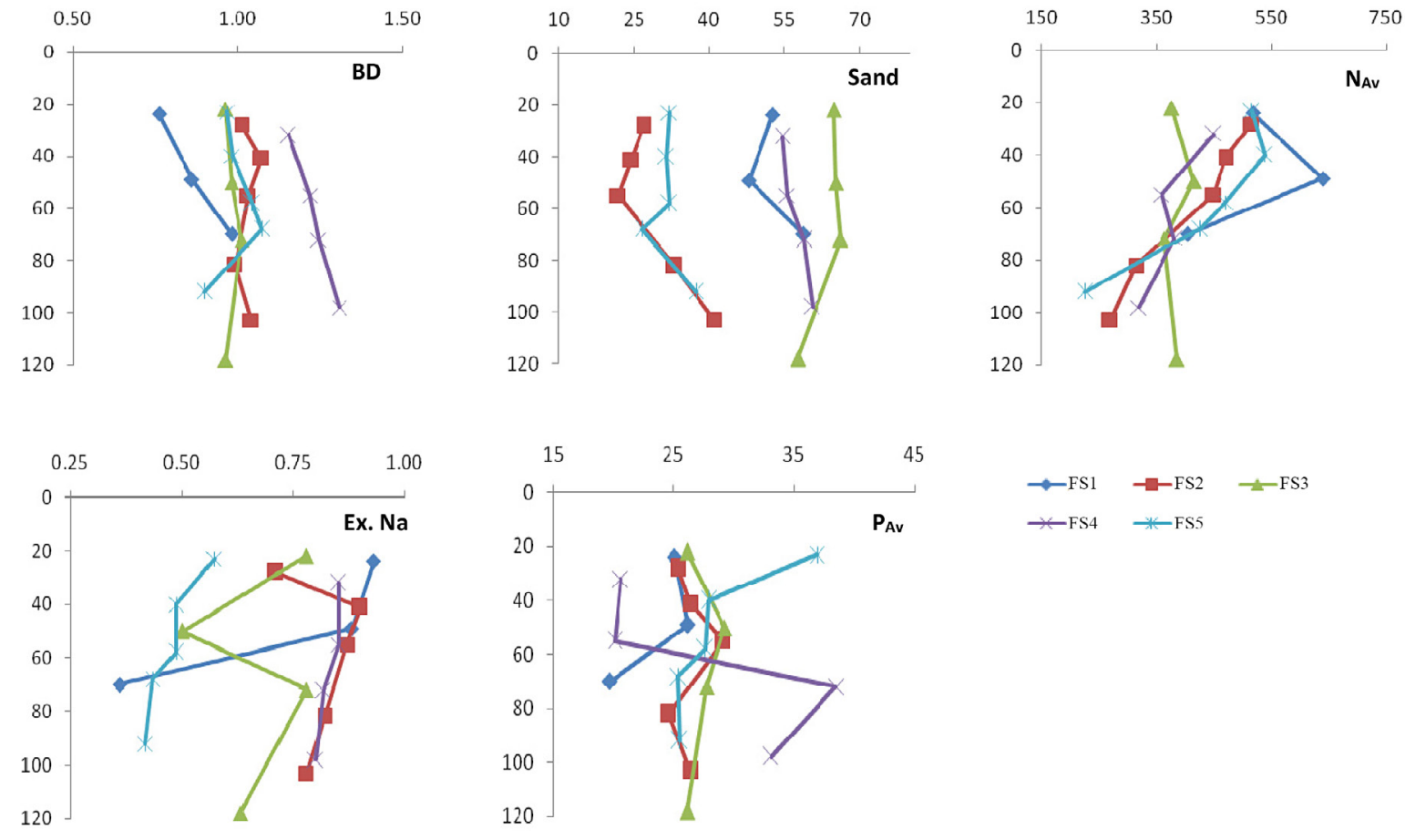

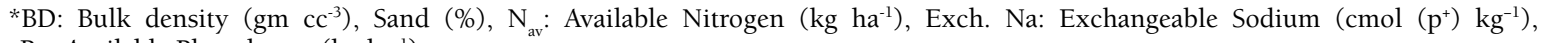
$\mathrm{P}_{\mathrm{av}}$ : Available Phosphorus $\left(\mathrm{kg} \mathrm{ha}^{-1}\right)$ 
Appendix 5. Depth-wise distribution of soil indicators, selected after principal component analysis, for each profile under Jhum lands
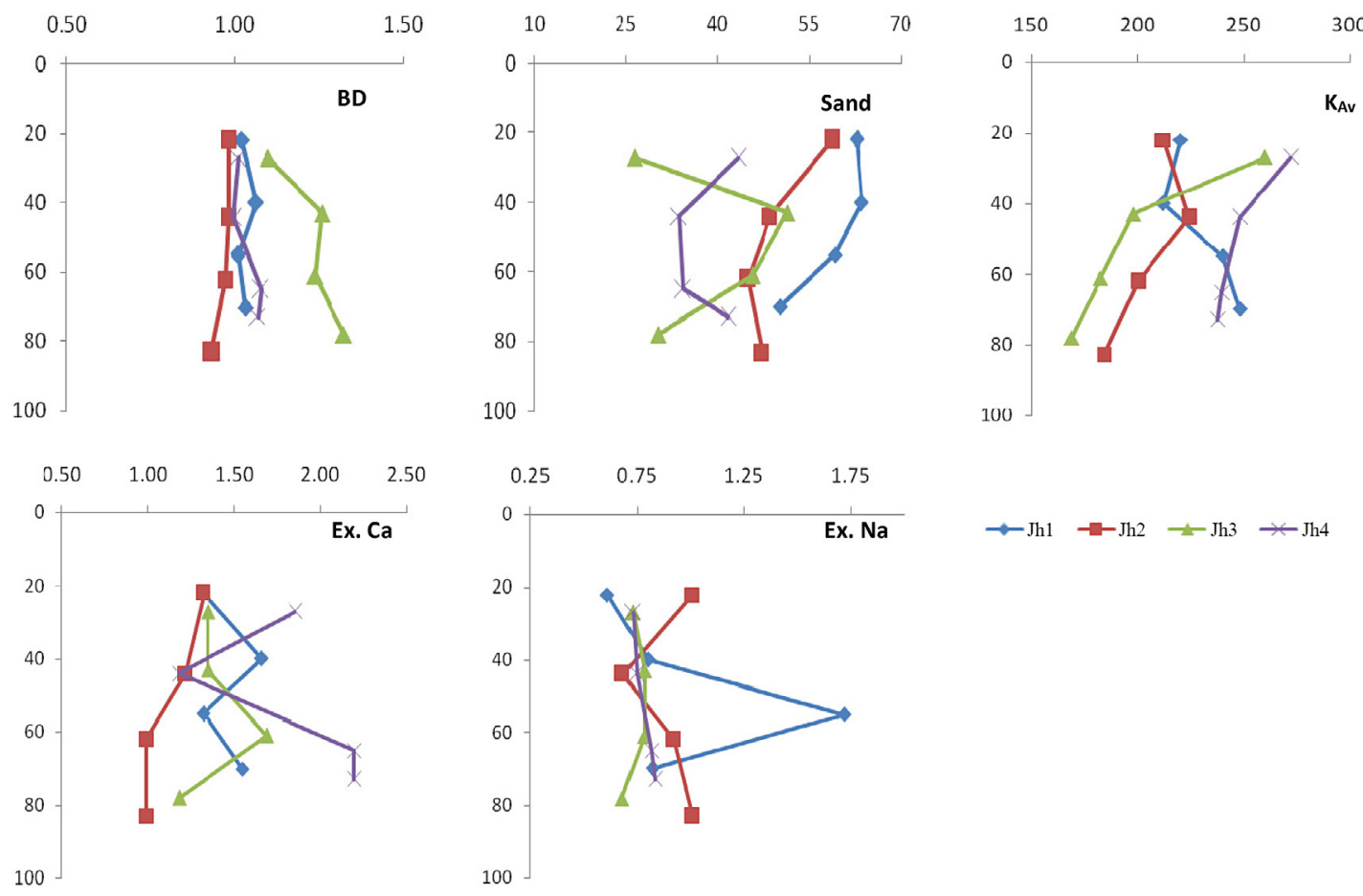

*BD: Bulk density $\left(\mathrm{gm} \mathrm{cc}^{-3}\right)$, Sand (\%), $\mathrm{K}_{\mathrm{a}}$ : Available Potassium $\left(\mathrm{kg} \mathrm{ha}^{-1}\right)$, Exch. Ca: Exchangeable Calcium $\left(\mathrm{cmol}\left(\mathrm{p}^{+}\right) \mathrm{kg}^{-1}\right)$, Exch. Na: Exchangeable Sodium $\left(\mathrm{cmol}\left(\mathrm{p}^{+}\right) \mathrm{kg}^{-1}\right)$

\section{Own elaboration}

Appendix 6. Depth-wise distribution of soil indicators, selected after principal component analysis, for each profile under fallow jhum lands.
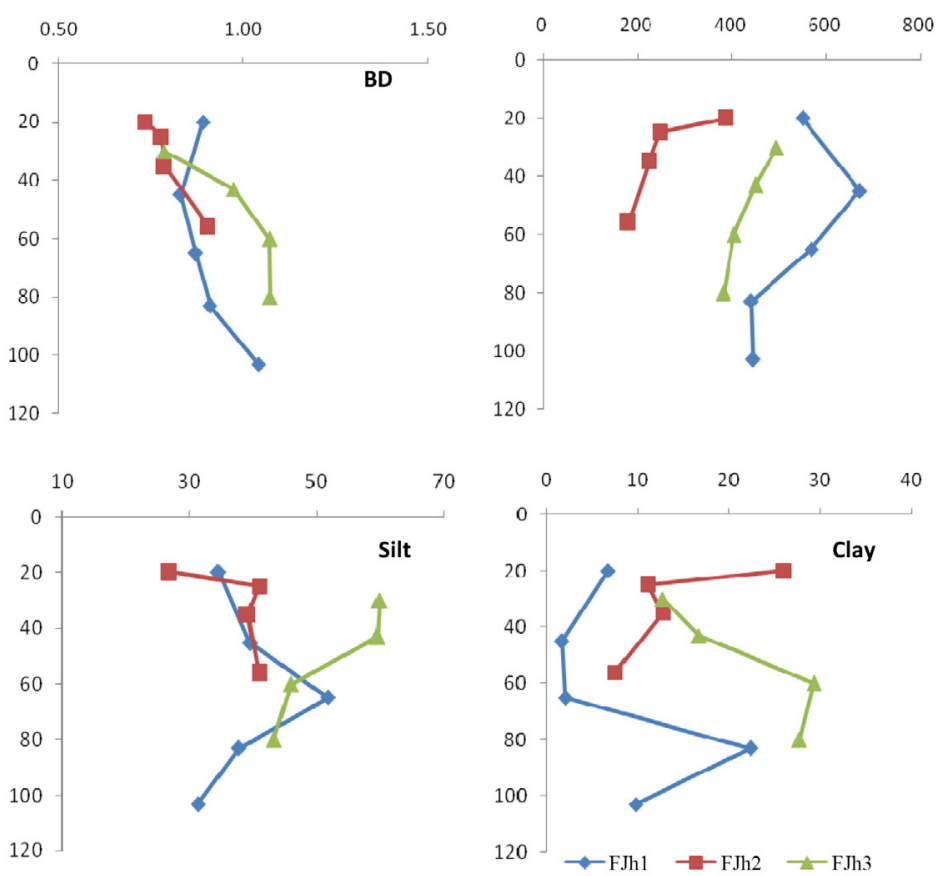

${ }^{*}$ BD: Bulk density $\left(\mathrm{gm} \mathrm{cc}^{-3}\right), \mathrm{N}_{\mathrm{av}}$ : Available Nitrogen $\left(\mathrm{kgha}^{-1}\right)$, Silt (\%), Clay (\%)

Own elaboration 


\section{Rerefences}

Andrews, S.S., Flora, C.B., Mitchell, J.P., \& Karlen, D.L. (2003). Grower's perceptions and acceptance of soil quality indices. Geoderma, 114(3-4), 187-213. https://doi.org/10.1016/S0016-7061(03)00041-7

Andrews, S.S., Karlen, D.L., \& Mitchell, J.P. (2002). A comparison of soil quality indices methods for vegetable production system in northern California. Agriculture, Ecosystems \& Environment, 90(1), 25-45. https://doi.org/10.1016/S0167-8809(01)00174-8

Armenise, E., Redmile-Gordon, M.A., Stellacci, A.M., Ciccarese, A., Rubino, P. (2013). Developing a soil quality index to compare soil fitness for agricultural use under different managements in the Mediterranean environment. Soil and Tillage Research, 130, 91-98. https://doi.org/10.1016/j. $\underline{\text { still.2013.02.013 }}$

Arunachalam, A. (2002). Dynamics of soil nutrients and microbial biomass during first year cropping in an 8-year jhum cycle. Nutrient Cycling in Agroecosystems, 64(3), 283-291. https://doi. org/10.1023/A:1021488621394

Assefa, F., Elias, E., Soromessa, T., \& Ayele, G. T. (2020). Effect of Changes in Land-Use Management Practices on Soil Physicochemical Properties in Kabe Watershed, Ethiopia. Air, Soil and Water Research, 13, 1178622120939587. https://doi.org/10.1177/1178622120939587

Askari, M.S., \& Holden, N.M. (2015). Quantitative soil quality indexing of temperate arable management systems. Soil and Tillage Research, 150, 57-67. https://doi.org/10.1016/j.still.2015.01.010

Askin, T., \& Ozdemir, N. (2003). Soil bulk density as related to soil particle size distribution and organic matter content. Poljoprivreda/Agriculture, 9, 52-55

Ayoubi, S., Khormali, F., Sahrawat, K.L., \& Rodrigues, de Lima, A.C. (2011). Assessing impacts of land use change on soil quality indicators in a loessial soil in Golestan Province Iran. Journal of Agricultural Science and Technology, 13(5), 727-742. http://oar.icrisat.org/id/eprint/1272

Bhaskar, B.P., Butte, P.S., \& UtpalBrauah, S. (2005). Characterization of soils in the 'Bil' environs of Brahmaputra valley in Jorhat district, Assam for landuse interpretation. Journal of the Indian Society of Soil Science, 53, 3-10.

Blake, G.R., \& Hartge, K.H. (1986). Bulk density. In A. Klute (Ed.), Methods of Soil Analysis Part 1, Physical and Mineralogical Methods, second ed. SSSA Book Series No. 5 (pp. 951-984). https://doi. org/10.1002/gea.3340050110

Bray, RH., \& Kurtz, L.T. (1945). Determination of total, organic and available forms of phosphorus in soils. Soil Science, 59, 39-46. http://dx.doi.org/10.1097/00010694-194501000-00006

Brejda, J.J., \& Moorman, T.B. (2001). Identification and interpretation of regional soil quality factors for the central high plains of the Midwestern USA. In D.E. Stott, R.H. Mohtar and G.C. Steinhardt (Eds), Sustaining the global farm (pp. 535-540). Selected papers from the 10th International Soil Conservation Organisation Meeting held during May 24-29 at Purdue University and the USDA-ARS National Soil Erosion Research Laboratory.

Caravaca, F., Figueroa, D., Barea, J.M., Azcón-Aguilar, C., Palenzuela, J., \&Roldán, A. (2003). The role of relict vegetation in maintaining physical, chemical, and biological properties in an abandoned stipa-grass agroecosystem. Arid Land Research and Management, 17(2), 103-111. https://doi. org/10.1080/15324980301585

Ceccarelli, T., Bajocco, S., Luigi Perini, L., \& Luca Salvati, L. (2014). Urbanisation and Land Take of High Quality Agricultural Soils-Exploring Long-term Land Use Changes and Land Capability in Northern Italy. International Journal of Environmental Research, 8(1), 181-192. https://doi.org/10.22059/ ijer.2014.707

Chaplot, V., Bouahom, B., \& Valentin, C. (2010). Soil organic carbon stocks in Laos: spatial variations and controlling factors. Global Change Biology, 16(4), 1380-1393. https://doi.org/10.1111/j.13652486.2009.02013.x

Chase, P., \& Singh, O.P. (2014). Soil nutrients and fertility in three traditional land use systems of Khonoma, Nagaland, India. Resources and Environment, 4(4),181-189.

Chaudhari, P.R., Ahire, D.V., Ahire, V.D., Chkravarty, M., \& Maity, S. (2013). Soil bulk density as related to soil texture, organic matter content and available total nutrients of Coimbatore soil. International Journal of Scientific and Research Publications, 3(2), 1-8. 
Cho, K.M., Zoebisch, M.A., \& Ranamukhaarachchi, S.L. (2004). Land-use dependent soil quality in the Lam PhraPhloeng watershed, northeast Thailand. In 13th International Soil Conservation Organisation Conference on "Conserving Soil and Water for Society: Sharing Solutions" (paper no. 119).Brisbane: ISCO. Retrieved from https://www.tucson.ars.ag.gov/isco/iscol3/PAPERS\%20A-E/ CHO.pdf

Colantoni, A., Ferrara, C., Perini, L., \& Salvati, L. (2015). Assessing trends in climate aridity and vulnerability to soil degradation in Italy. Ecological Indicators, 48, 599-604. https://doi.org/10.1016/j. ecolind.2014.09.031

Coyle, D. R., Nagendra, U. J., Taylor, M. K., Campbell, J. H., Cunard, C. E., Joslin, A. H., ... Callaham Jr., M. A. (2017). Soil fauna responses to natural disturbances, invasive species, and global climate change: Current state of the science and a call to action. Soil Biology and Biochemistry, 110, 116-133. https://doi.org/10.1016/j.soilbio.2017.03.008

Dalling, J.W., Heineman, K., Lopez, O.R, Wright, S.W., \& Turner, B.L. (2016). Nutrient Availability in Tropical Rain Forests: The Paradigm of Phosphorus Limitation. In G. Goldstein \& L. S. Santiago (Eds.), Tropical Tree Physiology (pp. 261-273). https://doi.org/10.1007/978-3-319-27422-5_12

Dikici, H., \& Yilmaz, C.H. (2006). Peat fire effects on some properties of an artificially drained peatland. Journal of environmental Quality, 35, 866-870. https://doi.org/10.2134/jeq2005.0170

Dong, S.K., Wen, L., Li, Y.Y., Wang, X.X., Zhu, L., \& Li, X.Y. (2012). Soil-quality effects of grassland degradation and restoration on the Qinghai-Tibetan Plateau. Soil Science Society of America Journal, 76(6), 2256-2264. https://doi.org/10.2136/sssaj2012.0092

Enaruvbe, G. O., \& Atafo, O. P. (2019). Land cover transition and fragmentation of River Ogba catchment in Benin City, Nigeria. Sustainable Cities and Society, 45, 70-78. https://doi.org/10.1016/j. $\underline{\text { scs.2018.11.022 }}$

FAO. (1957). Shifting cultivation. Unasylva, 11, 9-11.

Granged, A.J.P., Zavala, L.M., Jordan, A., \& Moreno, G.B., 2011. Post-fire evolution of soil properties and vegetation cover in a Mediterranean heathland after experimental burning: a 3-year study. Geoderma, 164, 85-94. https://doi.org/10.1016/j.geoderma.2011.05.017

Gbejewoh, O., Keesstra, S., \& Blancquaert, E. (2021). The 3Ps (Profit, Planet, and People) of Sustainability amidst Climate Change: A South African Grape and Wine Perspective. Sustainability, 13(5), 2910. https://doi.org/10.3390/su13052910

Handayani, I.P. (2004). Soil quality changes following forest clearance in Bengkulu,Sumatra. Biotropia, 22, 15-28. https://doi.org/10.11598/btb.2004.0.22.205

Inoue, Y., Kiyono, Y., Asai, H., Ochiai, Y., Qi, J., Olioso, A., ..., \& Dounagsavanh, L. (2010). Assessing land-use and carbon stock in slash-and-burn ecosystems in tropical mountain of Laos based on timeseries satellite images. International Journal of Applied Earth Observation and Geoinformation, 12(4), 287-297.

IPCC. (2007). In L. Bernstein, P. Bosch, O. Canzioni, O., Z. Chen, R. Christ, O. Davidson, ... \&G. Yohe. (Eds.), Climate Change 2007: Synthesis report. An assessment of the intergovernmental panel on climate change. Valencia, Spain: IPCC. Retrieved from http://www.ipcc.ch/pdf/assessmentreport/ar4/syr/ar4 syr.pdf. http://www.ipcc.ch/publications_and_data/ar4/syr/e...

IUSS Working Group WRB. (2015). World reference base for soil resources 2014, update 2015 international soil classification system for naming soils and creating legends for soil maps. Rome: FAO. (World Soil Resources Reports No. 106).

Khaledian, Y., Brevik, E.C., Pereira, P., Cerdà, A., Fattah, M.A., \& Tazikeh, H. (2017). Modeling soil cation exchange capacity in multiple countries. Catena, 158, 194-200. https://doi.org/10.1016/j. catena.2017.07.002

Khan, M.A., \& Kamalakar, J. (2012). Physical, physico-chemical and chemical properties of soils of newly established Agro-biodiversity Park of Acharya NG Ranga Agricultural University, Hyderabad, Andhra Pradesh. International Journal of Farm Sciences, 2(2), 102-116.

Kholodov V.A., Yaroslavtseva N.V, Farkhodov Y.R., Belobrov V.P., Yudin S.A., Aydiev A.Ya., ..., \& Frid A.S. (2019). Changes in the Ratio of Aggregate Fractions in Humus Horizons of Chernozems in Response to the Type of Their Use. Eurasian Soil Science, 52(2), 162-170. https://doi.org/10.1134/ $\underline{\text { S1064229319020066 }}$ 
Klute, A. (Ed.) (1986). Methods of Soil Analysis: Part 1. Physical and Mineralogical Methods. In Soil Science Society of America Book Series, No. 5 (pp. 687-734). Madison, Wisconsin: Soil Science Society of America.

Leskiw, L.A. (1998) Land capability classification for forest ecosystem in the oil stands region. Edmonton: Alberia Environmental Protection.

Li, P., Zhang, T., Wang, X., \& Yu, D. (2013). Development of biological soil quality indicator system for subtropical China. Soil and Tillage Research, 126, 112-118. https://doi.org/10.1016/j.still.2012.07.011

Liu, Z.J., Zhou, W., Shen, J.B, Li, S.T, Liang, G.Q., Wang, X.B., \& Sun J-W. (2014). Soil quality assessment of acid sulfate paddy soils with different productivities in Guangdong Province, China. Journal of Integrative Agriculture, 13(1), 177-186. https://doi.org/10.1016/S2095-3119(13)60594-8

Lohbeck, M., Poorter, L., Martínez-Ramos, M., \& Bongers, F. (2015). Biomass is the main driver of changes in ecosystem. Ecology, 96, 1242-1252. https://doi.org/10.1890/14-0472.1

Lungmuanaa, Singha, S.B., Vanthawmliana, Saha, S., Duttaa, S.K., Rambuatsaiha, Singh, A.R., \& Boopathia, T. (2017). Impact of secondary forest fallow period on soil microbial biomass carbon and enzyme activity dynamics under shifting cultivation in North Eastern Hill region, India. Catena, 156, 10-17. https://doi.org/10.1016/j.catena.2017.03.017

Marzaioli, R., D’Ascoli, R., De Pascale, R.A., \& Rutigliano, F.A. (2010). Soil quality in a Mediterranean area of Southern Italy as related to different land use types. Applied Soil Ecology, 44(3), $205-212$. https://doi.org/10.1016/j.apsoil.2009.12.007

Mendoza-Vega, J., \& Messing, I. (2005). The influence of land use and fallow period on the properties of two calcareous soils in the humid tropics of southern Mexico. Catena, 60, 279-292. https://doi. org/10.1016/j.catena.2004.12.002

Mishra, G., Marzaioli, R., Giri, K., Borah, R., Dutta, A., \& Jayaraj, R.S.C. (2017). Soil quality assessment under shifting cultivation and forests in Northeastern Himalaya of India. Archives of Agronomy and Soil Science, 63(10), 1355-1368. https://doi.org/10.1080/03650340.2017.1281390

Mishra, G., Jangir, A., \& Francaviglia, R. (2019). Modeling soil organic carbon dynamics under shifting cultivation and forests using RothC model. Ecological Modeling, 396, 33-41. https://doi.org/10.1016/j. ecolmodel.2019.01.016,

Mishra, G., \& Sarkar, A (2020). Studying the relationship between total organic carbon and soil carbon pools under different land management systems of Garo hills, Meghalaya. Journal of Environmental Management, 257, 1 March 2020, 10002. https://doi.org/10.1016/j.jenvman.2019.110002

Mulugeta, L., Karltun, E., \& Olsson, M. (2005). Assessing soil chemical and physical property responses to deforestation and subsequent cultivation in smallholders farming system in Ethiopia. Agriculture, Ecosystems E Environment, 105(1-2),373-386. https://doi.org/10.1016/j.agee.2004.01.046

Nega, E., \& Heluf, G. (2009). Influence of land use changes and soil depth on cation exchange capacity and contents of exchangeable bases in the soils of Senbat Watershed, western Ethiopia. Ethiopian Journal of Natural Resources, 11(2), 195-206.

NRC (National Research Council). (1981). Surface Mining: Soil, Coal and Society. New York: National Academy Press. https://doi.org/10.17226/19654

Patel, T., Karmakar, S., Sanjog, J., Kumar, S., \& Chowdhury, A. (2013). Socio-economic and environmental changes with transition from shifting to settled cultivation in North-Eastern India: an ergonomics perspective. International Journal of Agricultural Science and Research, 3(2), 117-136.

Pierce, FJ., Larson, W.E., Dowdy, R.H., \& Graham, W.A.P. (1983). Productivity of soils: assessing longterm changes due to erosion. Journal of Soil and Water Conservation, 38(1), 39-44.

Poorter, L., van der Sande, M.T., Thompson, J., Arets, E.J., Alarcón, A., Álvarez-Sánchez, J. ... \& Peña-Claros M. (2015). Diversity enhances carbon storage in tropical forests. Global Ecology and Biogeography, 24(11), 1314-1328. https://doi.org/10.1111/geb.12364

Post, W.M., \& Kwon, K.C. (2000). Soil carbon sequestration and land-use change: processes and potential. Global change biology, 6(3), 317-327. https://doi.org/10.1046/j.1365-2486.2000.00308.x

Pulido, M., Schnabel, S., Lavado-Contador, J.F., Miralles Mellado, I., Ortega \&Pérez, R. (2013). Soil organic matter of Iberian open woodland rangelands as influenced by vegetation cover and land management. Catena, 109, 13-24. https://doi.org/10.1016/j.catena.2013.05.002 
Pulido, M., Keshavarzi, A., Rodrigo-Comino, J., Schnabel, S., Contador, J. F. L., Gutiérrez, Á. G., ... Cerdà, A. (2020). Developing scoring functions to assess soil quality at a regional scale in rangelands of SW Spain. Rev. Bras. Ciênc. Solo, 44. https://doi.org/10.36783/18069657rbcs20200090

Ramakrishnan, P.S., \& Toky, O.P. (1981). Soil nutrient status of hill agroecosystems and recovery pattern after slash and burn agriculture (jhum) in north-eastern India. Plant and Soil, 60(1), 41-64. http:// dx.doi.org/10.1007/BF02377111

Rao, P.S.C., \& Wagenet, R.J. (1985). Spatial variability of field soils: methods for data analysis and consequences. Weed Science, 33(S2), 18-24. https://doi.org/10.1017/S0043174500083764

Rathore, S.S. (2008). Paradigm shift for enhancing rice productivity in Nagaland: Existing practices and their refinement. Himalayan Eco, 16(2), 17-25.

Rawls, R.J., Gimenez, D., \& Grossman, R. (1998). Use of soil texture, bulk density, and slope of the water retention curve to predict saturated hydraulic conductivity. Transactions of the ASABE, 41, 983-988. https://doi.org/10.13031/2013.17270

Ribeiro Filho, A.A., Adams, C., \& Murrieta, R.S.S. (2013). The impacts of shifting cultivation on tropical forest soil: a review. Boletim do Museu Paraense Emílio Goeldi. Ciências Humanas, 8(3), 693-727. https://doi.org/10.1590/S1981-81222013000300013

Rodrigo-Comino, J., Keshavarzi, A., Bagherzadeh, A., \&Brevik, E.C., (2019). The use of multivariate statistical analysis and soil quality indices as tools to be included in regional management plans. A case study from the Mashhad Plain, Iran. Cuadernos de Investigación Geográfica, 45, 687-708. https:// doi.org/10.18172/cig.3640

Rodrigo-Comino, J., Terol, E., Mora, G., Giménez-Morera, A., \& Cerdà, A. (2020). Vicia sativa Roth. Can Reduce Soil and Water Losses in Recently Planted Vineyards (Vitis vinifera L.). Earth Systems and Environment, 4(4), 827-842. https://doi.org/10.1007/s41748-020-00191-5

Rodrigo-Comino, J., López-Vicente, M., Kumar, V., Rodríguez-Seijo, A., Valkó, O., Rojas, C., ... Panagos, P. (2020). Soil Science Challenges in a New Era: A Transdisciplinary Overview of Relevant Topics. Air, Soil and Water Research, 13, 1178622120977491. https://doi.org/10.1177/1178622120977491

Saha, R., Chaudhary, R.S., \& Somasundaram, J. (2012). Soil health management under hill agroecosystem of North East India. Applied and Environmental Soil Science, 1-9. https://doi.org/10.1155/2012/696174

Salehi, A., Wilhelmsson, E., \& Soderberg, U. (2008). Land cover changes in a forested watershed, southern Zagros, Iran. Land Degradation \& Development, 19(5), 542-553. https://doi.org/10.1002/ldr.860

Salvati, L., Bajocco, S., Ceccarelli, T., Zitti, M., \& Perini, L. (2011). Towards a process-based evaluation of land vulnerability to soil degradation in Italy. Ecological Indicators, 11(5), 1216-1227. https://doi. org/10.1016/j.ecolind.2010.12.024

Sánchez-Navarro, A., Gil-Vázquez, J. M., Delgado-Iniesta, M. J., Marín-Sanleandro, P., Blanco-Bernardeau, A., \& Ortiz-Silla, R. (2015). Establishing an index and identification of limiting parameters for characterizing soil quality in Mediterranean ecosystems. Catena, 131, 35-45. http://dx.doi. org/10.1016/j.catena.2015.02.023

Sarkar, D., Meitei, Ch.B., Baishya, L.K., Das, A., Ghosh, S., Chongloi, K.L., \& Rajkhowa, D.J. (2015). Potential of fallow chronosequence in shifting cultivation to conserve soil organic carbon in northeast India. Catena, 135, 321-327. https://doi.org/10.1016/j.catena.2015.08.012

Schollenberger, C.J., \& Simon, R.H., (1945). Determination of exchange capacity and exchangeable bases in soil. Ammonium acetate method. Soil Science, 59(1), 13-24. http://dx.doi.org/10.1097/00010694$\underline{194501000-00004}$

Sharma, C.M., Gairola, S., Ghildiyal, S.K., \& Suyal S. (2010). Physical Properties of Soils in Relation to Forest Composition in Moist Temperate Valley Slopes of the Central Western Himalaya. Journal of Forest and Environmental Science, 26(2), 117-129.

Shukla, M.K., Lal, R., \& Ebinger, M. 2006. Determining soil quality indicators by factor analysis. Soil and Tillage Research, 87(2), 194-204. https://doi.org/10.1016/j.still.2005.03.011

Singh, A.K., Bordoloi, L.J., Kumar, M., Hazarika, S., \& Parmar, B. (2014). Land use impact on soil quality in eastern Himalayan region of India. Environmental Monitoring and Assessment, 186(4), 2013-2024. https://doi.org/10.1007/s10661-013-3514-7 
Subbiah, B., \& Asija, C.L. (1956). A rapid procedure for the estimation of available nitrogen in soils. Curr Sci., 25(8), 256-260.

Sulieman, M., Saeed, I., Hassaballa, A.,\&Rodrigo-Comino, J. (2018). Modeling cation exchange capacity in multi geochronological-derived alluvium soils: An approach based on soil depth intervals. Catena, 167, 327-339. https://doi.org/10.1016/j.catena. 2018.05.001

Sumner, M.E., \& Miller, W.P. (1996). Cation exchange capacity and exchange coefficients. In D.L. Sparks, A.L. Page, P.A. Helmke (Eds.), Methods of Soil Analysis Part 3, Chemical Methods (pp. 1201-1229). Madison, Wisconsin, USA: Soil Science Society of America. https://doi.org/10.2136/sssabookser5.3.c40

Tawnenga, Shankar, U., \& Tripathi, R.S. (1997). Evaluating second year cropping on jhum fallows in Mizoram, north-eastern India: soil fertility. Journal of Biosciences, 22(5), 615-625. https://doi. org/10.1007/BF02703398

USDA Natural Resources Conservation Service. (2004). In R. Burc (Ed.), Soil Survey Laboratory Methods Manual. Soil Survey Investigations Report No. 42, Version 4. O. (pp. 1031). Lincoln, NE: National Soil Survey Center.

Vasu, D., Singh, S. K., Ray, S.K., Duraisami, V.P., Tiwary, P., Chandran, P., .., \& Anantwar S.G. (2016). Soil quality index (SQI) as a tool to evaluate crop productivity in semi-arid Deccan plateau, India. Geoderma, 282, 70-79. https://doi.org/10.1016/j.geoderma.2016.07.010

Vinhal-Freitasa, I.C.., Correa, G.F., Wendling, B., Bobul'skác, L., \& Ferreira, A.S. (2017). Soil textural class plays a major role in evaluating the effects of land use on soil quality indicators. Ecological indicators, 74 , 182-190. https://doi.org/10.1016/j.ecolind.2016.11.020

Visser, S., Keesstra, S., Maas, G., de Cleen, M., \& Molenaar, C. (2019). Soil as a Basis to Create Enabling Conditions for Transitions Towards Sustainable Land Management as a Key to Achieve the SDGs by 2030. Sustainability, 11, 6792. https://doi.org/10.3390/sul1236792

Walkley, A., \& Black, I.A. (1934). An examination of the Degtjareff method for determining soil organic matter and a proposed modification of the chromic acid titration method. Soil Science, 37(1), 29-38. http://dx.doi.org/10.1097/00010694-193401000-00003

Yadav, P.K. (2013). Slash-and-burn agriculture in north-East India. Expert Opinion Environmental Biology, 2, 1-4. https://doi.org/10.4172/2325-9655.1000102 